\title{
Validation of an Integrated Hydrogen Energy Station
}

\author{
DOE Cooperative Agreement \\ DE-FC36-01G011087
}

\section{FINAL REPORT}

For the period

30 September 2001 - 31 December 2011

\section{Prime Contractor:}

Air Products and Chemicals, Inc.

Principal Investigator: Edward C. Heydorn

Subcontractor:

FuelCell Energy, Inc.

Team Member:

National Fuel Cell Research Center

University of California, Irvine

Funding Agencies:

California Air Resources Board

South Coast Air Quality Management District

Orange County Sanitation District

\section{October 2012}




\section{Disclaimer}

The statements and conclusions in this report are those of the grantee and not necessarily those of the California Air Resources Board. The mention of commercial products, their source, or their use in connection with material reported herein is not to be construed as actual or implied endorsement of such products.

This report was prepared as a result of work sponsored and paid for, in whole or in part, by the South Coast Air Quality Management District (AQMD). The opinions, findings, conclusions, and recommendations are those of the author and do not necessarily represent the views of AQMD. AQMD, its officers, employees, contractors, and subcontractors make no warranty, expressed or implied, and assume no legal liability for the information. AQMD has not approved or disapproved this presentation, nor has AQMD passed upon the accuracy or adequacy of the information contained herein. 


\section{Acknowledgments}

The authors wish to acknowledge the following for their contributions:

Air Products: Ed Heydorn, Carolyn Caporuscio, Ed Weist

FuelCell Energy: Pinakin Patel, Fred Jahnke, Matt Lambrech, Joe Daly, Jeff Brown

National Fuel Cell Research Center: Jack Brouwer, Scott Samuelsen, Roxana Bekemohammadi

DOE: Sunita Satyapal, John Garbak, Jim Alkire, Fred Joseck

CA Air Resources Board: Gerhard Achtelik, Mike Kashuba

Orange County Sanitation District: Jeff Brown, Jim Mullens, Kim Christensen, Ed Torres, Chris MacLeod 


\section{EXECUTIVE SUMMARY}

This report presents the results of a 10-year project conducted by Air Products and Chemicals, Inc. (Air Products) to determine the feasibility of coproducing hydrogen with electricity. The primary objective was to demonstrate the technical and economic viability of a hydrogen energy station using a high-temperature fuel cell designed to produce power and hydrogen. This fourphase project had intermediate go/no-go decisions and the following specific goals:

- Complete a technical assessment and economic analysis of the use of hightemperature fuel cells, including solid oxide and molten carbonate, for the coproduction of power and hydrogen (energy park concept).

- Build on the experience gained at the Las Vegas $\mathrm{H}_{2}$ Energy Station and compare/contrast the two approaches for co-production.

- Determine the applicability of co-production from a high-temperature fuel cell for the existing merchant hydrogen market and for the emerging hydrogen economy.

- Demonstrate the concept on natural gas for six months at a suitable site with demand for both hydrogen and electricity.

- Maintain safety as the top priority in the system design and operation.

- Obtain adequate operational data to provide the basis for future commercial activities, including hydrogen fueling stations.

Work began with the execution of the cooperative agreement with DOE on 30 September 2001. During Phase 1, Air Products identified high-temperature fuel cells as having the potential to meet the coproduction targets, and the molten carbonate fuel cell system from FuelCell Energy, Inc. (FuelCell Energy) was selected by Air Products and DOE following the feasibility assessment performed during Phase 2. Detailed design, construction and shop validation testing of a system to produce $250 \mathrm{~kW}$ of electricity and 100 kilograms per day of hydrogen, along with site selection to include a renewable feedstock for the fuel cell, were completed in Phase 3 . The system also completed six months of demonstration operation at the wastewater treatment facility operated by Orange County Sanitation District (OCSD, Fountain Valley, CA).

As part of achieving the objective of operating on a renewable feedstock, Air Products secured additional funding via an award from the California Air Resources Board. The South Coast Air Quality Management District also provided cost share which supported the objectives of this project.

System operation at OCSD confirmed the results from shop validation testing performed during Phase 3. Hydrogen was produced at rates and purity that met the targets from the system design basis, and coproduction efficiency exceeded the 50\% target set in conjunction with input from the DOE. Hydrogen production economics, updated from the Phase 2 analysis, showed pricing of $\$ 5$ to $\$ 6$ per kilogram of hydrogen using current gas purification systems. Hydrogen costs under $\$ 3$ per kilogram are achievable if next-generation electrochemical separation technologies become available. 


\section{LIST OF FIGURES}

Figure 1 Technology/product development process.

Figure 2 PEM-based power production flow diagram.

Figure 3 High-temperature fuel cell (HTFC) coproduction schematic.

Figure 4 Integration of a PEM fuel cell with a high-temperature fuel cell.

Figure $5 \quad$ DFC- $\mathrm{H}_{2}$ reformer concept to produce hydrogen and electricity.

Figure 6 Overall energy balance for the hydrogen energy station.

Figure 7 Hydrogen energy station economics (Phase 2).

Figure 8 Renewable feedstocks for the hydrogen energy station.

Figure 9 Detailed process flow diagram for the hydrogen energy station.

Figure 10 Computer-aided design model for the anode exhaust gas system.

Figure 11 Cooling system within the anode exhaust gas system.

Figure 12 FuelCell Energy DFC-300 and mechanical balance of plant (MBOP).

Figure 13 Hydrogen extraction from the DFC-300 module.

Figure 14 Anode exhaust gas skid at the shop validation test.

Figure 15 Hydrogen energy system compression system.

Figure 16 Pressure swing adsorption system.

Figure 17 Hydrogen energy station installation at the shop validation test.

Figure 18 Hydrogen energy station operating results at the shop validation test.

Figure 19 Snapshot of hydrogen energy station performance on 31 August 2009.

Figure 20 Hydrogen energy station overall heat and mass balance (28 August 2009).

Figure 21 Hydrogen energy station emissions during shop validation testing.

Figure 22 Overview of hydrogen production from anaerobic digester gas via the hydrogen energy station.

Figure 23 Relative locations of the hydrogen energy station and hydrogen fueling station.

Figure 24 Layout of the hydrogen energy station at OCSD..

Figure 25 Process flow diagram: supply of digester gas for hydrogen energy station.

Figure 26 Installation of the anode exhaust gas skid at OCSD.

Figure 27 Installation of interconnecting piping between the DFC-300 and pressure swing adsorption system at OCSD (ground level).

Figure 28 Installation of interconnecting piping between the DFC-300 and pressure swing adsorption system at OCSD (from above).

Figure 29 Installation progress at OCSD.

Figure 30 Installation of hydrogen energy station at OCSD (24 August 2010).

Figure 31 Operating results from the hydrogen energy station at OCSD, Sept. 2010-Feb. 2011.

Figure 32 Snapshot of hydrogen energy station performance on 27 October 2010.

Figure 33 Installation of the ADG clean-up system at OCSD.

Figure 34 Performance of the ADG clean-up system on 31 May 2011.

Figure 35 Performance of the ADG clean-up system on 23 February 2012.

Figure 36 Performance of the ADG clean-up system on 14 March 2012.

Figure 37 Causes of operating trips at OCSD, October 2010-March 2012.

Figure 38 Snapshot of hydrogen energy station performance on 28 July 2011.

Figure 39 Measurements of coproduction efficiency at OCSD.

Figure 40 Operations summary at OCSD through April 2012.

Figure 41 Hydrogen energy station economics (updated 2011). 


\section{LIST OF TABLES}

Table 1 Natural gas to electricity efficiencies for PEM fuel cells and conventional technologies.

Table 2 Coproduction economics from high-temperature fuel cells (Phase 1).

Table 3 Schedule of engineering activities under Phases 2 and 3.

Table 4 Schedule of installation at OCSD.

Table 5 Measurements of coproduction efficiency at OCSD. 


\section{TABLE OF CONTENTS}

EXECUTIVE SUMMARY i

LIST OF FIGURES Ii

LIST OF TABLES iii

$\begin{array}{ll}\text { 1. INTRODUCTION } & 1\end{array}$

2. RESULTS 2

2.1 Phase 1 - Study of the Optimum Power Park Supply Device to Match a Typical Load Profile 2

2.2 Phase 2 - Engineering Development, Preliminary Design, Detailed Cost Estimate and Site Selection 8

2.3 Phase 3 - Detailed Design, Fabrication and Shop Testing 13

2.3.1 Process Description 13

2.3.2 Timetable and Design Highlights 16

$\begin{array}{lll}\text { 2.3.3 Shop Validation Testing } & 18\end{array}$

2.4 Phase 4 - Installation, Start-up, Operation and Data Collection 24

3. PRESENTATIONS/PUBLICATIONS/PATENTS 37 


\section{INTRODUCTION}

One of the immediate challenges in the development of hydrogen as a transportation fuel is finding the optimal means to roll out a hydrogen-fueling infrastructure concurrent with the deployment of hydrogen vehicles. In locations with excess production capacity, hydrogen can be provided at rates currently paid by industrial users and can be supplied to local stations with additional costs for distribution and dispensing equipment. When new capacity is required, several existing hydrogen production options can be implemented to meet the fueling demand, such as adding larger central capacity and/or smaller distributed systems. The low-volume hydrogen requirements in the early years of fuel cell vehicle deployment make the economic viability of stand-alone, distributed hydrogen generators challenging. Some systems, such as reformers, cannot be readily started, stopped and thermally cycled to match the daily fueling pattern for light-duty vehicles (peaks in the morning, midday, and the afternoon). In order to match the production and demand requirements for distributed generation, additional onsite storage of hydrogen or venting of unused hydrogen will be needed - which results in poor asset utilization and increased cost of hydrogen to the end user. Costs for environmental controls and analytical systems will also be higher per unit of hydrogen produced from a smaller distributed system. Turndown of the hydrogen generator is possible (for example, to $50 \%$ for a reformer), but this results in higher hydrogen costs because the capital asset is used less effectively.

A possible solution to this "underutilized asset" problem is to evaluate the potential for generating multiple products while operating the generator at full rates, thus improving the capital utilization of the system. In 2001, Air Products and Chemicals, Inc. (Air Products) was awarded a cooperative agreement by the U.S. Department of Energy (DOE) to evaluate and validate this coproduction concept using a series of go/no-go points. Figure 1 describes the process that was utilized to coordinate the technology and product development activities. This approach provided check points at the Concept and Feasibility steps and included specific cost and performance targets that needed to be satisfied before proceeding to the next phase. The proposed pathway, called a hydrogen energy station, uses a high-temperature fuel cell to coproduce electricity as the primary energy stream, with hydrogen as a higher-value coproduct.

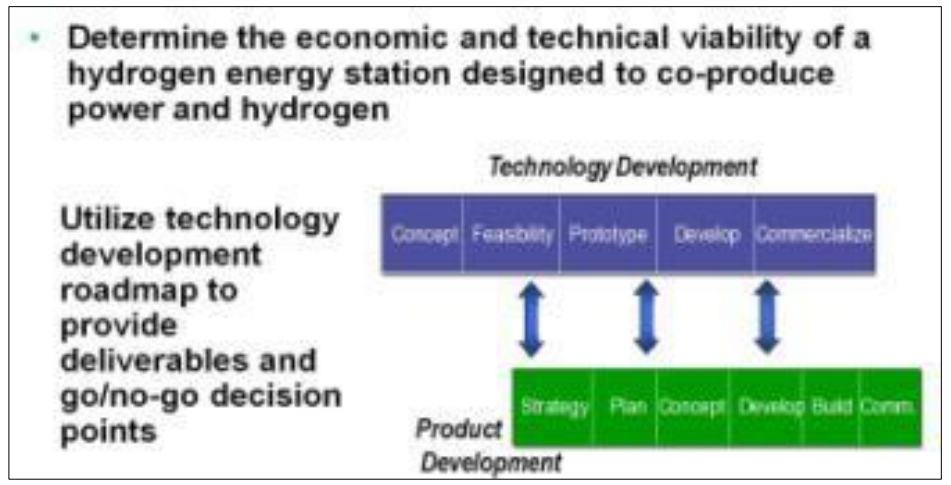

Figure 1. Technology/product development process. 


\section{RESULTS}

\subsection{Phase 1: Study of the Optimum Power Park Supply Device to Match a Typical Load Profile}

In this phase of the program, the goal of the initial work was to develop an optimized power generation system with natural gas as the fuel and proton exchange membrane (PEM) fuel cells providing the conversion to electricity. The first step was to identify all possible processes at the time that could be used to produce power from natural gas. This included reformer systems ranging from 50 to 200 kilowatts (kW), so a $100 \mathrm{~kW}$ system was chosen as the base case. At the time of the work, PEM cells were available in the range of 3 to $5 \mathrm{~kW}$, and these were scaled linearly to system size. Table 1 shows the results of surveys from three PEM fuel cell manufacturers regarding subsystem component efficiencies, and an estimate of future potential efficiency and cost for PEM systems in this application. These figures can be compared with the performance of other natural-gas based power generators that are provided for reference.

Table 1. Natural gas to electricity efficiencies for PEM fuel cells and conventional technologies.

\begin{tabular}{|c|c|c|c|c|c|}
\hline Subsystem & Today & Future & FC Company 1 & $\begin{array}{c}\text { FC Company } 2 \\
1-250 \mathrm{~kW}\end{array}$ & FC Company 3 \\
\hline $\begin{array}{l}\text { Reformer + } \\
\text { Purification }\end{array}$ & $75 \%$ & $80 \%$ & $75 \%$ & $76 \%$ & $75 \%$ \\
\hline Balance of Plant & $90 \%$ & $90 \%$ & $100 \%$ & $100 \%$ & $90 \%$ \\
\hline Anode Eff & $100 \%$ & $100 \%$ & $85 \%$ & $78 \%$ & $100 \%$ \\
\hline PEM & $52 \%$ & $62 \%$ & $52 \%$ & $52 \%$ & $53 \%$ \\
\hline Electrical Conversion & $90 \%$ & $90 \%$ & $81 \%$ & $92 \%$ & $85 \%$ \\
\hline Total Efficiency & $31.59 \%$ & $40.18 \%$ & $26.85 \%$ & $28.36 \%$ & $30.41 \%$ \\
\hline \multirow[t]{2}{*}{ Total Cost } & $\$ 14,000 / \mathrm{kW}$ & $\$ 3,300 / \mathrm{kW}$ & & & \\
\hline & $\begin{array}{l}\text { NG Recip } \\
>200 \mathrm{~kW}\end{array}$ & $\begin{array}{c}\text { Micro } \\
\text { turbine } \\
30-500 \mathrm{~kW}\end{array}$ & $\begin{array}{l}\text { Stirling } \\
30-60 \mathrm{~kW}\end{array}$ & $\begin{array}{c}\text { Small Turbine } \\
>500 \mathrm{~kW}\end{array}$ & $\begin{array}{c}\text { CCGT } \\
>20 \mathrm{MW}\end{array}$ \\
\hline Efficiency & $38 \%$ & $27 \%$ & $30 \%$ & $35 \%$ & $40 \%$ \\
\hline Cost & $\$ 1,000 / \mathrm{kW}$ & $\$ 3,000 / \mathrm{kW}$ & $\$ 3,000 / \mathrm{kW}$ & $\$ 1,200 / \mathrm{kW}$ & $\$ 850 / \mathrm{kW}$ \\
\hline
\end{tabular}

Aspen Plus ${ }^{\circledR}$ modeling software was used to simulate each process to determine system efficiency and waste heat content in the exhaust gas streams. Construction costs were estimated using in-house methods and an example identified by Penn State University with three buildings located 200 yards (each) from a central location. Capital cost information was then collected from all available vendors of reformers, purification systems and fuel cells. A cost of power model was built to provide rapid calculations while changing inputs.

Assumptions used in the economic modeling include:

- System utilization: 95\% (baseload operation)

- After-tax return: 10\% (DCF basis)

- Overhead: $20 \%$ of capital

- Insurance and property taxes: $2.5 \%$ of capital

- Taxes: $35 \%$ federal, $3 \%$ state and local

- Inflation: $2.5 \%$ 
- Book and economic life: 10 years

- Natural gas: \$5.65/MMBTU (HHV) (10 year average commercial rate, 2000 dollars)

- Electricity: \$0.0822/kWh (10 year average commercial rate, 2000 dollars)

This analysis produced the following results:

1. The overall efficiency ranged from 25 to $33 \%$ for a natural gas-to-electricity system using a distributed steam methane reformer with hydrogen purification by pressure-swing adsorption feeding a PEM fuel cell (Figure 2). Power costs were determined to be $\$ 0.45$ per kWh at the current PEM capital cost of $\$ 14,000$ per kW, and $\$ 0.14$ per kWh based on a future PEM cost of $\$ 3,300$ per kWh. The current cost of power was consistent with results published by Directed Technologies, Inc. ${ }^{1}$ in 1999. Impurities in the natural gas stream would be eliminated by sulfur removal systems as part of the reformer package, so the risk of poisons reaching the highest-cost component (PEM) would be minimal.

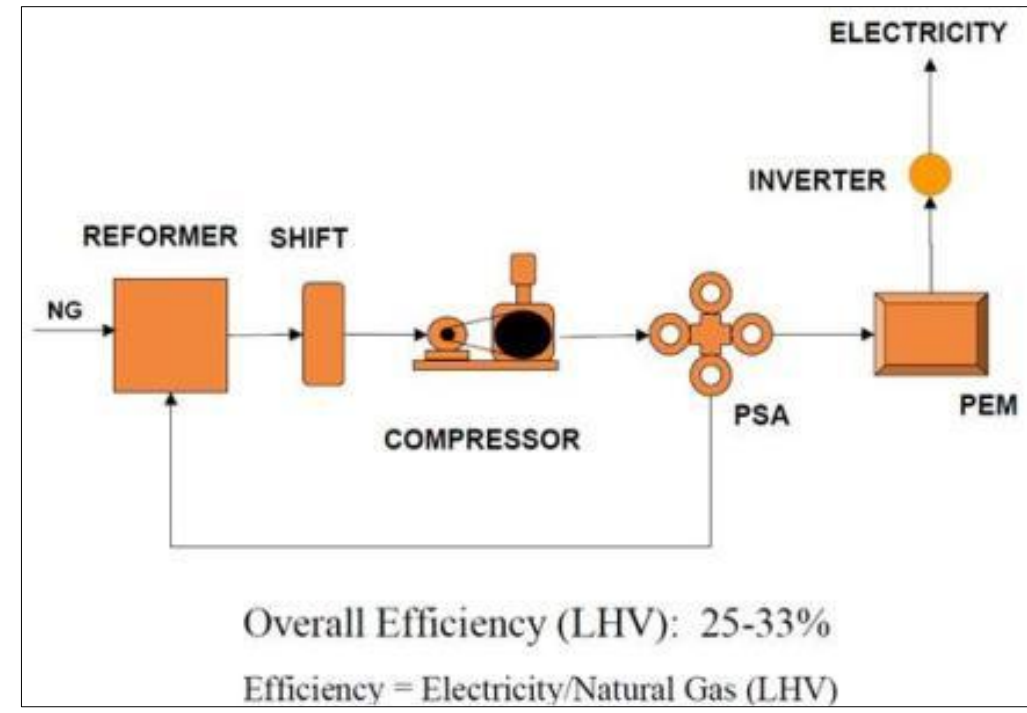

Figure 2. PEM-based power production flow diagram.

2. One consideration during this phase was to compare the cost of power production at the central facility with distribution of electricity via wire versus piping hydrogen product to distributed PEM fuel cells at each building. The installed cost for wiring over the distances used in this study appeared to be half the installed cost of the hydrogen piping.

3. If heat recovery were added to the exhaust gas from the reforming process or the fuel cell, power cost could be reduced by $\$ 0.01 / \mathrm{kWh}$. There are considerations to the addition of this equipment to the process:

a. Any heat recovery will require that the heat source be located near the heating load. The co-location of a large reformer with a PEM system appeared to be the most viable case that was considered, especially with larger systems that take advantage of the economies of scale for the entire process. A power production of $250 \mathrm{~kW}$ appears to be the minimum level where the economics become feasible. For applications such as hospitals, apartments, prisons, dormitories, and warehouses with cooling requirements, the power needs approach $800 \mathrm{~kW}$, which will yield even more favorable economics.

b. Based on the available credits during the period of study $(\$ 0.013 / \mathrm{kWh}$ applied to commercial utility rates, $\$ 0.008 / \mathrm{kWh}$ applied to industrial rates), there appears to be a limited amount of investment that can be justified for heat integration from the 
PEM-based system. One way to limit the tie-in costs to heating/ventilation/air conditioning (HVAC) systems is to more fully integrate the two processes. For example, a hot water boiler/adsorptive chiller arrangement for the HVAC requirements can operate at approximately $80 \%$ efficiency. For the PEM-based arrangement in Figure 2, the amount of excess heat corresponds to around $90 \%$ of the total electrical output of the process. This means that over $70 \%$ of the excess heat could be recovered using the boiler/chiller system.

c. Another result of the HVAC analysis (item b) was that hot water distribution appears to be cost-prohibitive for most heat integration applications.

4. Another scenario evaluated was the use of PEM fuel cells based on the availability of existing hydrogen resources. These would include offgas systems and, potentially, pipeline hydrogen networks that could have excess capacity. Although this configuration has merit based on operability (low noise) and low emissions (important for areas with air quality issues), these would appear to be more of a niche application and were not considered to meet the objectives of this scope of work.

The next step was a sensitivity calculation to determine the fuel cost, utilization, capital cost and efficiency required to achieve a DOE target electricity cost of $\$ 0.10 / \mathrm{kWh}$. These results identified the required size, operating mode, cost and efficiency to meet the target. Based on the same assumptions used in the development of the base economic model, all of the following changes would be needed to achieve the target cost:

- $25 \%$ increase in overall efficiency (from $33 \%$ to $40 \%$ )

- $4000 \%$ increase in fuel cell life (from guarantee value of 3,000 hours)

- $500 \%$ increase in power output (to achieve $800 \mathrm{~kW}$ needed for industrial gas rates)

- $95 \%$ reduction in PEM costs and $75 \%$ reduction of reformer costs

PEM cost reductions could be achieved with mass production and could be driven by both government activities (direct purchases or credits) and by enabling other applications beyond stationary power production (i.e., use in light-duty vehicles or buses).

At this stage of the project, an assessment of hybrid systems that can coproduce hydrogen with electricity and power was added to the evaluation. High-temperature fuel cells (HTFCs) are well known to produce hydrogen internally at a very high efficiency for use in the fuel cell reaction, as well as for export. As shown in Figure 3, offgas from the fuel cell can conceptually be collected and fed to a purification system for production of high-purity hydrogen.

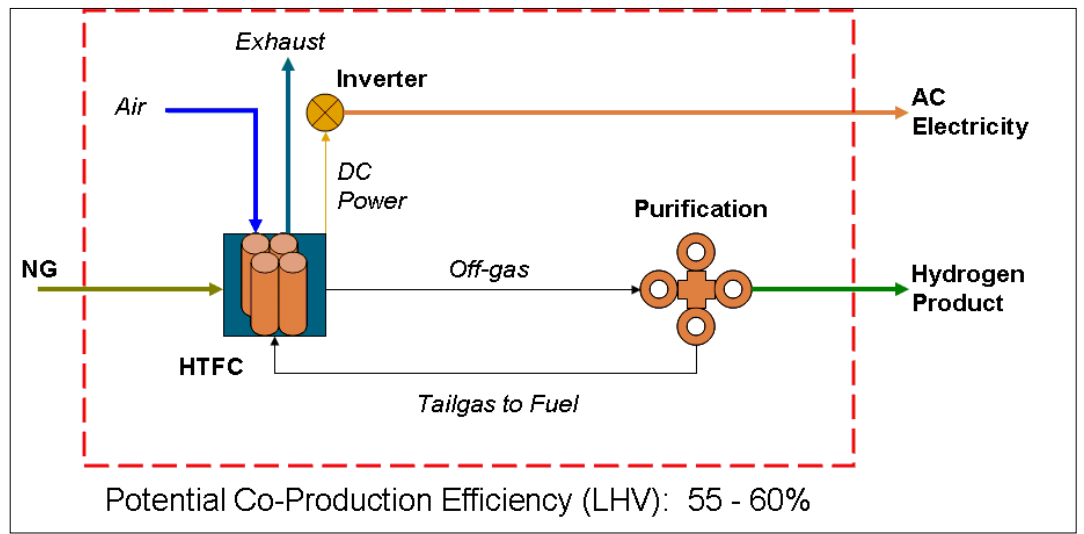

Figure 3. High-temperature fuel cell (HTFC) coproduction schematic. 
This expanded "power park" concept, which was first considered during Phase 1 activities, is summarized in Figure 4. In this scenario, a PEM fuel cell could be integrated with a hightemperature fuel cell can. Either natural gas or biogas from waste treatment facilities could be supplied to the high-temperature fuel cell, and hydrogen can be directed either to a PEM system for additional power production (e.g., to take advantage of peak power pricing) or to other uses (e.g., the hydrogen refueling station shown in Figure 4). Electricity can be supplied to the local grid, and waste heat can be recovered and utilized.

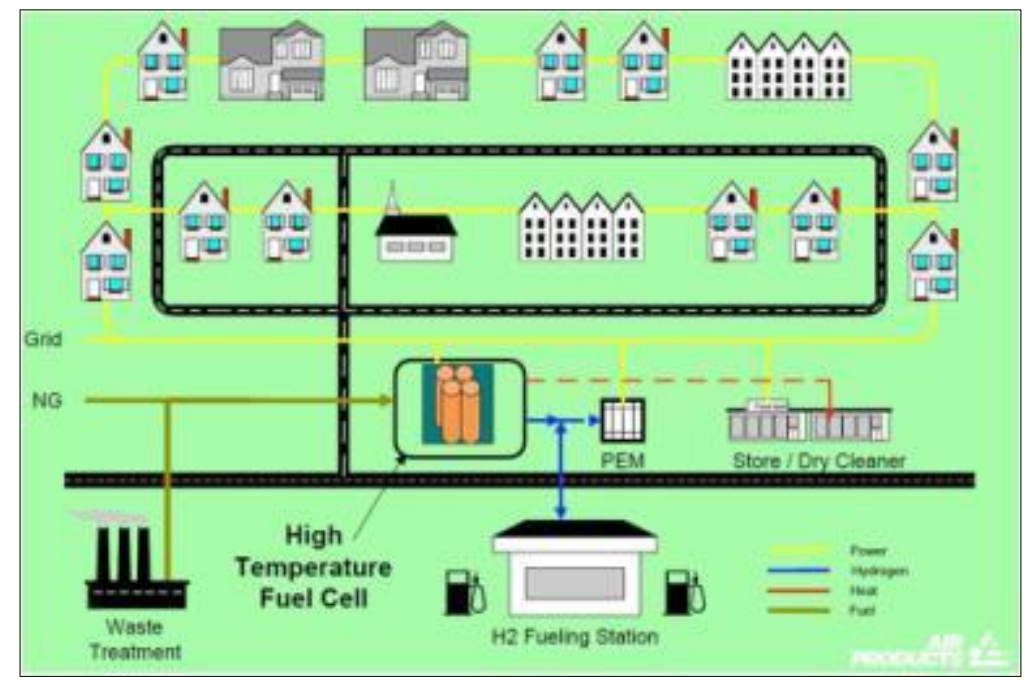

Figure 4. Integration of a PEM fuel cell with a high-temperature fuel cell.

This initial analysis identified the following benefits of coproduction from a high-temperature fuel cell:

- High efficiency

- Low emissions

- Potential use of waste hydrocarbons as a fuel source, producing renewable hydrogen and electricity

- Grid benefits

- Multiple product slate that improves capital utilization and provides for flexible product pricing options

- Potential integration with a low-temperature fuel cell in a hybrid power cycle

A preliminary feasibility study was undertaken using the information from this literature search. Heat and material balances were developed using Aspen Plus ${ }^{\circledR}$ simulation software, and an economic model was written to evaluate coproduction scenarios.

To further validate the technical and economic feasibility of the coproduction concept, three high-temperature fuel cell vendors - two using solid oxide fuel cell (SOFC) technologies and one using molten carbonate fuel cell (MCFC) technology - were approached to provide information on the feasibility of coproduction using their existing HTFC technologies. Air Products developed preliminary product specifications that were given to each vendor for this purpose. The suppliers provided preliminary coproduction schemes, along with fuel cell performance and cost projections, flow diagrams, and process data. Air Products provided hydrogen purification expertise as necessary and performed a detailed economic analysis on the overall system. The results from the economic analysis were used to determine the nearterm commercial viability in the merchant hydrogen market as well as the emerging hydrogen economy. 
As shown in Table 2, high-temperature fuel cells configured to coproduce hydrogen have the potential to meet the DOE hydrogen cost targets while producing power for less than $\$ 0.10$ / kW. Table 2 also shows the economic results for three scenarios as well as a few of the key assumptions for each scenario. These results are based on the financial and operating assumptions listed in Table 3.1.2 of DOE's Multi-Year Research, Development, and Demonstration Plan (MYRDDP).

It should be noted that the economics are based on coproduction systems that produce 690 $\mathrm{kg} /$ day of high-purity hydrogen while producing over $1.5 \mathrm{MW}$ of AC electricity. Furthermore, it is important to note that the cost of the HTFC is assumed to decrease from \$2,250 per kW in 2005 to $\$ 800$ per kW in 2015 .

Table 2. Coproduction economics from high-temperature fuel cells (Phase 1).

\begin{tabular}{|c|c|c|c|}
\hline & 2005 & 2010 & 2015 \\
\hline Hydrogen, kg/day ${ }^{*}$ & 690 & 690 & 690 \\
\hline Net Electricity, kw & $>1.5 \mathrm{MW}$ & $>1.5 \mathrm{MW}$ & $>1.5 \mathrm{MW}$ \\
\hline HTFC Cost, S/kW AC w/o H2 & 2250 & 1200 & 800 \\
\hline Natural Gas Costs, \$immbtu* & 4.00 & 4.00 & 4.00 \\
\hline Production Volume, units/year" & 100 & 100 & 100 \\
\hline Fueling Utilization* & $90 \%$ & $90 \%$ & $90 \%$ \\
\hline Capital Factor & 0.11 & 0.11 & 0.11 \\
\hline \multicolumn{4}{|l|}{ Base Energy Price } \\
\hline Hydrogen Price, $\$ / \mathrm{kg}$ & 2.97 & 2.15 & 1.88 \\
\hline Power Price, \$/kwh & 0.07 & 0.05 & 0.05 \\
\hline \multicolumn{4}{|l|}{ Fueling Scenario } \\
\hline Hydrogen at the Pump, $\$ / \mathrm{kg}^{*}$ & 3.00 & 1.50 & 1.50 \\
\hline \multicolumn{4}{|l|}{ Station Allocation, $\$ / \mathrm{kg}^{*}$} \\
\hline Compression, $\$ / \mathrm{kg} \mathrm{H}^{*}$ & -0.29 & -0.24 & -0.24 \\
\hline Storage \& Dispensing, \$/kg $\mathrm{H}_{2}$ * & -0.19 & -0.11 & -0.11 \\
\hline Hydrogen Production Price, \$ \$/kg & 2.52 & 1.15 & 1.15 \\
\hline Power Price, \$ikwh & 0.08 & 0.07 & 0.06 \\
\hline
\end{tabular}

"Assumptions from the DOE Multi-Year Research, Development and Demonstration Plan, Table 3.1.2, page 3- 10. Draft 6/3/03

The cost information under the heading "Base Energy Price" in Table 2 represents the equivalent cost of energy across the product electricity and hydrogen from the coproduction system. It can be seen that the 2005 scenario produced hydrogen at $\$ 2.97$ per $\mathrm{kg}$ while producing power at $\$ 0.07$ per $\mathrm{kWh}$. This dropped to $\$ 1.88$ per $\mathrm{kg}$ and $\$ 0.05 \mathrm{per} \mathrm{kWh}$, respectively, in the 2015 scenario.

The cost information under the heading "Fueling Scenario" represents the targets set by the DOE in the MYRDDP for fueling station applications. The DOE hydrogen cost targets at the pump were $\$ 3.00$ per $\mathrm{kg}$ in 2005 and $\$ 1.50$ per $\mathrm{kg}$ in 2010 and 2015 . The costs associated with compression, storage, and dispensing are DOE targets that are subtracted from the pump price to arrive at the required cost of hydrogen from the coproduction unit. For example, in 2005, the target price for hydrogen is $\$ 3.00$ per $\mathrm{kg}$ at the pump. Subtracting the cost of compression, storage, and dispensing from the pump price leaves $\$ 2.52 \mathrm{per} \mathrm{kg}$ for hydrogen production. At this hydrogen price, electricity must be sold for $\$ 0.08$ per $\mathrm{kWh}$ for the coproduction system to produce the revenue required for an acceptable economic rate of return. As can be seen in Table 2, hydrogen can be sold at the DOE target prices while selling power for much less than $\$ 0.10 / \mathrm{kWh}$ in all three scenarios. Finally, comparing the Fueling Scenario results with the Base 
Energy prices shows that, in all scenarios, the revenue from the power is subsidizing the hydrogen product price.

The work completed during Phase 1 showed that high-temperature fuel cells configured to coproduce hydrogen and electricity can result in significantly lower costs for distributed hydrogen production while simultaneously generating power at commercially-attractive rates. As a result, high-temperature fuel cells that coproduce hydrogen and electricity may offer a potentially attractive method to roll out a hydrogen fueling infrastructure.

- High-temperature fuel cells configured to coproduce hydrogen and electricity are able to meet the DOE hydrogen targets as specified in the MYRDDP while producing power for $<\$ 0.10 / \mathrm{kWh}$.

- Both MCFCs and SOFCs can be designed for coproduction.

- Coproduction efficiencies were similar at 55\%-60\% (lower heating value - LHV)

- Both technologies have the potential to meet the DOE targets while producing power for $<\$ 0.10 / \mathrm{kW}$.

- Several areas for engineering development were identified to move the coproduction concept forward:

- Anode off-gas recovery and conditioning;

- Low parasitic power hydrogen purification;

- Impacts of both steady-state operation and dynamic response;

- System integration;

- Optimization of coproduced products.

In December 2004, Air Products recommended to DOE that the project proceed to Phase 2 activities, starting with the preliminary engineering design of a combined electric power and hydrogen production system. 


\subsection{Phase 2: Engineering Development, Preliminary Design, Detailed Cost Estimate and Site Selection}

At the conclusion of Phase 1, Air Products submitted a recommendation to DOE to proceed with the engineering development and preliminary design to co-produce hydrogen and power from a high-temperature fuel cell. If the technical and economic evaluations continue to be favorable at the conclusion of a 6-9 month development period (Phase 2), DOE and Air Products should consider a demonstration. Since SOFC systems were not available at $\mathrm{kW}$-size power outputs, Air Products selected the DFC ${ }^{\circledR}$ (Direct Fuel Cell) molten carbonate system from FuelCell Energy, Inc. (FCE) for concept development. The selection was based on several factors:

1) FCE's DFC technology offers a near-term, cost-effective opportunity to demonstrate the concept of co-production of hydrogen and electricity at the $250 \mathrm{~kW}$ level.

2) The DFC technology is a pre-commercial product, whereas other applicable HTFC technologies are still developmental. At the time of selection, 30 FCE fuel cells at commercial and industrial sites had produced over 35 million kWh of electricity.

3) The DFC technology utilizes internal reforming in the fuel cell, which makes the coproduction of hydrogen particularly cost effective, since there is no requirement for additional reforming equipment.

4) Because of their leading technology positions in both DFC and SOFC areas, FCE will bring a unique technology perspective to the program and the opportunity to apply the development work to its SOFC technology.

The proposed DFC- $\mathrm{H}_{2}$ hydrogen production concept, shown in Figure 5, is an innovative yet simple modification of the basic DFC product.

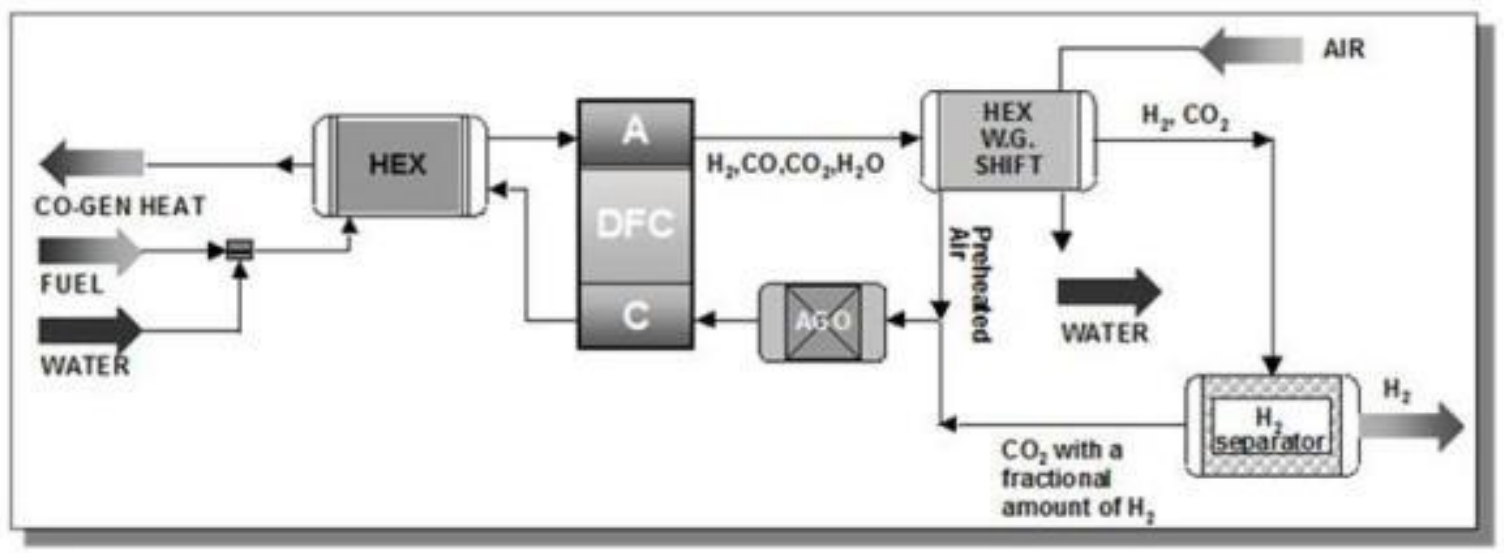

Figure 5. DFC- $\mathrm{H}_{2}$ reformer concept to produce hydrogen and electricity. Components needed for hydrogen production are shown.

All baseline DFC hardware remains the same, with the new process consisting of: 1) producing additional hydrogen from the anode exhaust with a shift reaction, 2) condensing water after the shift reactor, and 3) subsequently recovering hydrogen using a novel Air Products purification process. The following sequence of steps is used to recover hydrogen from the DFC anode exhaust to co-produce hydrogen and power:

1. The anode exhaust is cooled using a regenerative heat exchanger (HEX).

2. Additional hydrogen is produced with a water-gas shift to minimize $\mathrm{CO}$ concentration using a water-gas shift catalyst in an integrated HEX.

3. Water is condensed and recycled so that the DFC- $\mathrm{H}_{2}$ needs no external water source, except at start-up.

4. Carbon dioxide $\left(\mathrm{CO}_{2}\right)$ and other contaminants are separated from the hydrogen, and the hydrogen is purified. 
5. $\mathrm{CO}_{2}$ is mixed with incoming air and preheated in the cathode inlet of the regenerative heat exchanger.

$\mathrm{DFC}^{\circledR}$ technology is based on the reformation of hydrocarbons inside the fuel cell, integrating the synergistic benefits of the endothermic reforming reaction with the exothermic fuel cell reaction. The internal reforming of methane is driven by the heat generated in the fuel cell and simultaneously provides efficient cooling of the stack, which is needed for continuous operation. The steam produced in the anode reaction helps to drive the reforming reaction forward. The hydrogen produced in the reforming reaction is used directly in the anode reaction, which further enhances the conversion of hydrocarbons. This one-step process significantly reduces costs while maximizing chemical and electrical efficiency. In addition, DFC ${ }^{\circledR}$ power plants generate high-quality, by-product heat energy $\left(700^{\circ} \mathrm{F}\right)$ that can be harnessed for combined heat and power (CHP) applications. DFC ${ }^{\circledR}$ power plants in simple cycle provide an electrical efficiency of 47 percent, and, as shown in Figure 6, energy conversion approaching $90 \%$ is possible when hydrogen coproduction and waste heat recovery are included.

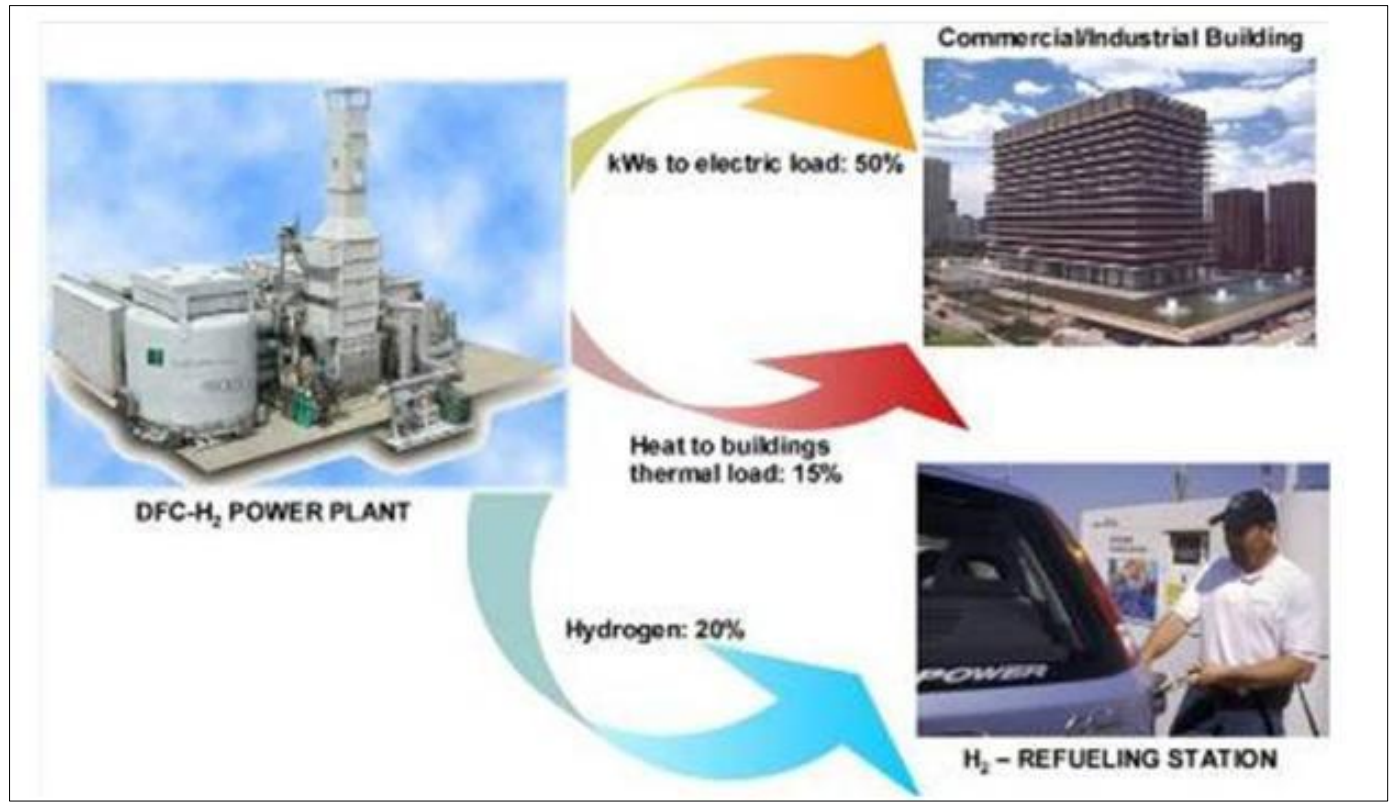

Figure 6. Overall energy balance for the hydrogen energy station.

The baseline electric $\mathrm{DFC}^{\circledR}$ is designed to operate at $75 \%$ fuel utilization in the stack. The remaining $25 \%$ of fuel from the anode presents a unique opportunity to produce cost-effective hydrogen if it can be recovered from the dilute anode effluent gases. The recovery and purification of hydrogen from the anode presents several challenges:

1) The anode off-gas is a low-pressure, high-temperature gas stream that contains $\sim 10 \%$ hydrogen by volume. The other components in this stream are by-product water, carbon dioxide and carbon monoxide. The total content of recoverable hydrogen is increased by a water-gas shift of carbon monoxide, condensing the water followed by a selective removal of carbon dioxide and other trace species.

2) The anode exhaust stream must be heat integrated with the fuel cell to ensure high overall system efficiency. Benefits of regenerative heat exchangers for fuel and oxidant streams were investigated to maximize the thermal efficiency and to minimize the supplemental fuel need, particularly at partial-load operation.

3) The parasitic power used for purification must be optimized with the hydrogen recovery and capital cost to enable an economically-viable solution. 
The overall objective of this task was to complete a detailed cost estimate for a combined hydrogen and power generator using FCE's $250 \mathrm{~kW}$ DFC power plant (DFC300 series) integrated with a hydrogen separation system selected by Air Products. Design efforts involved integrating FCE's existing $250 \mathrm{~kW}$ stack with the hydrogen generation system, as well as modifying the anode exhaust piping design to provide the hydrogen-containing stream for hydrogen separation. Also, a cooling train (regenerative heat exchanger) with a water-gas shift catalyst would be added to increase the hydrogen concentration and recover water. Other than these changes, the power plant equipment would remain the same as the standard FCE commercial offering. A go/no-go decision to proceed with detailed design and construction would be made after the completion of this phase.

FCE worked closely with Air Products to determine all interface parameters for the DFC power plant and hydrogen separation subsystems which could impact fuel cell design and performance. Thereafter, FCE focused its design efforts on cycle selection for the water-gas shift (WGS) reactor, water condenser, and heat recovery system. As a part of this evaluation, case study simulations were conducted at various fuel cell operating conditions (start-up, hot standby, full-power) to evaluate hydrogen availability and extraction from the anode exhaust fuel gas from the DFC $250 \mathrm{~kW}$ stack. The results were used to develop a heat and mass balance summary. The overall system design configuration was evaluated with respect to the impact of transient fuel cell conditions (especially start-up and shutdown of the hydrogen extraction and purification system) on individual components and overall system performance.

The WGS reactor design for additional hydrogen production was also developed, with low pressure drop being the major goal. The WGS would be chosen based on hydrogen generation and system performance. System design also included the impact of key components on system performance, such as the method to condense and return water.

Optimization analysis would include the impact of separation parameters and variations in anode tail gas flow and composition on parasitic power requirements and the quality of product hydrogen. A process HAZOP analysis was performed to ensure a safe design. Upon completion of this subtask, FCE developed a detailed design of the DFC- $\mathrm{H}_{2}$ product and the final test plan to demonstrate the integrated DFC- $\mathrm{H}_{2}$ system should the decision be made to proceed with system design and construction.

The technical challenge in the development of the hydrogen separation and purification stage was to recover and purify the hydrogen from a very dilute feed stream $(<20 \%$ hydrogen and $80 \% \mathrm{CO}_{2}$ ). Air Products used its extensive experience in gas separation to develop an optimized gas purification technology for this application. Three purification technologies were investigated:

1) Standalone pressure swing adsorption (PSA)

2) Standalone vacuum swing adsorption (VSA)

3) A physical solvent system for bulk $\mathrm{CO}_{2}$ removal in combination with a PSA

Air Products evaluated these options to determine the most cost-effective technology to remove the hydrogen from the fuel cell anode tail gas. As part of this evaluation, Air Products simulated preliminary designs and estimated costs for the proposed separation systems. The adsorption technology that provided the lowest cost of hydrogen would be selected. The following variables were considered in the design optimization:

1. Energy requirements

2. Percentage of hydrogen recovery 

3. Size (footprint)
4. Capital costs
5. Operating costs

The optimization analysis included the impact of separation parameters and variations in anode tail gas composition on parasitic power requirements and the quality of product hydrogen.

Air Products validated the simulation results used in the initial analysis, screened applicable adsorbents, and developed a detailed cost estimate with which to make a go/no-go decision prior to fabricating the selected adsorption system. Air Products' Adsorption Technology Center performed lab-scale testing as necessary using its state-of-the-art Process Development Units (PDUs). The adsorbent tests performed in the PDUs allowed Air Products to verify the design, optimize the adsorption cycle, and minimize the overall technology risk to the project. Air Products evaluated over 25 purification options and down-selected to an adsorption-based system that can recover over $85 \%$ of the hydrogen in the anode off-gas while using minimal electrical power.

\section{Task 2.3 - Detailed Cost Estimate}

Using the design information resulting from the work performed by Air Products and FuelCell Energy on the integrated fuel cell and hydrogen purification system, a preliminary design and a detailed cost estimate were completed for the full $\mathrm{H}_{2}$-electricity coproduction system. Economics were developed based on actual equipment, fabrication, and installation quotes, as well as new operating cost estimates. The estimate is based on the following parameters:

- Project life: 15 years

- Depreciation: 15 years

- Inflation: $1.9 \%$

- Tax depreciation: 5-year MACRS

- DCF return: $10 \%$

- Overheads: $20 \%$

- Taxes: $37.8 \%$

- Maintenance: Bottom-up estimation

Figure 7 provides a summary of the expected costs for hydrogen and electricity from a hydrogen energy station. This analysis assumes a common owner for the entire system, with the total financial return being the sum of the revenue from the sale of electricity and hydrogen. Three scenarios for capital and operating costs (including next-generation separation technologies) were assumed. Hydrogen is assumed to be delivered at $100 \mathrm{psig}$, so any additional capital and operating costs (e.g., if hydrogen were fed directly to a refueling station) were not included. Hydrogen pricing in the range of $\$ 2-\$ 3$ per kilogram was calculated based on longer-term projections of system capital and operating costs. 


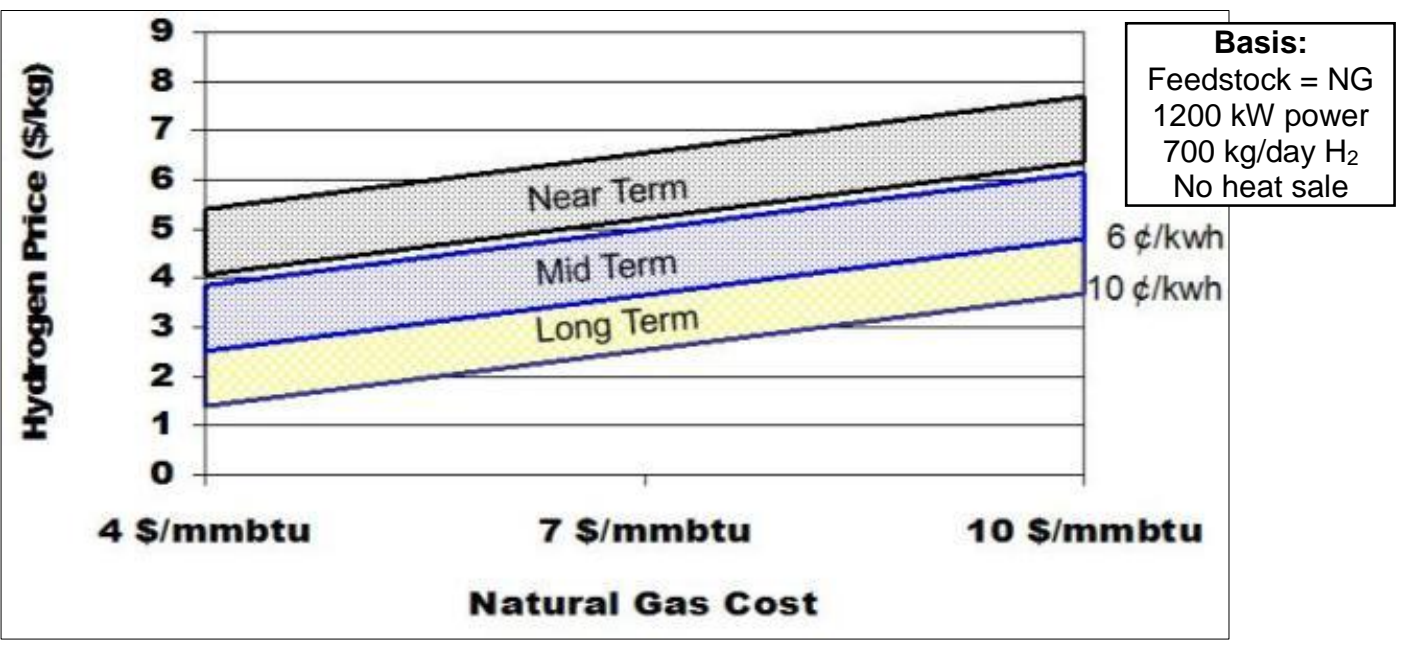

Figure 7. Hydrogen energy station economics (Phase 2).

As part of the evolution of the project, DOE requested that the objectives be modified to change the feedstock for Phase 4 operation from natural gas to a renewable feedstock. Work began in 2006 to identify a host site to meet this objective. Although this would add cost and time to the project, participants believed that meeting the vision of a renewable heat/power/hydrogen coproduction system (Figure 8) would be a valuable addition to the initial demonstration of the technology. Unlike many other power generation systems, DFC ${ }^{\circledR}$ power plants can operate on renewable fuels. Also, unlike other fuel cells, DFC ${ }^{\circledR}$ cells produce electrical power that is not derated due to the diluents in the methane-rich biogas.

A number of other methane-containing, renewable, potential feedstocks are listed in Figure 8. At the time of the potential host site evaluations, there were approximately $70 \mathrm{DFC}^{\circledR}$ fuel cells in use worldwide. Of these, 20 were operating on anaerobic digester gas (ADG), with half in use at wastewater treatment plants. More than five years of operating data were available for several of these systems. In addition to use with fuel-cell vehicles, co-product hydrogen can also be used in hydrogen-based internal combustion engines (HICE) and blended hydrogencompressed natural gas ( $\mathrm{HCNG}$ ) buses and vehicles to reduce $\mathrm{NO}_{\mathrm{x}}$ emissions. This strategy is expected to increase the capacity utilization factor to further improve the near-term economics.

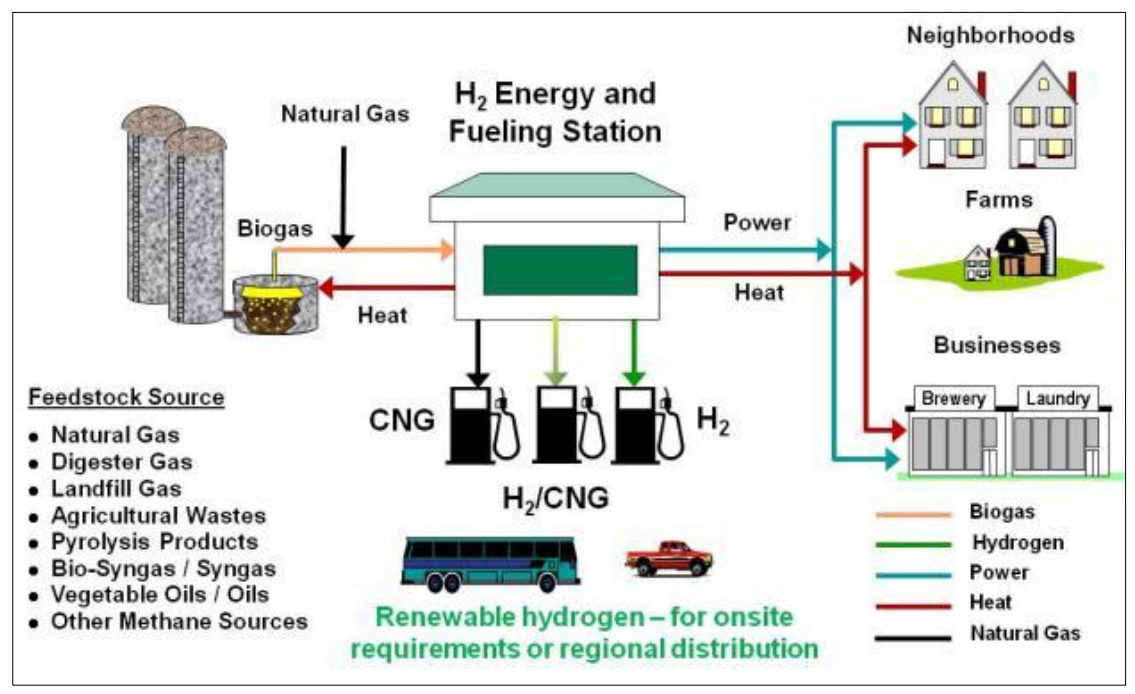

Figure 8. Renewable feedstocks for the hydrogen energy station. 
Based on the results of the work in Phase 2, Air Products submitted a continuation application to DOE to proceed with Phases 3 and 4 of the project. DOE approved the modification to the cooperative agreement on 21 September 2006.

\subsection{Phase 3: Detailed Design, Fabrication and Shop Testing}

DOE approval initiated Phase 3, which included the development of a detailed design for the coproduction system using the $\mathrm{DFC}^{\circledR} 300$ fuel cell as the platform. Due to the timing of DOE funding and availability of cost share from Air Products and FuelCell Energy, Phase 3 activities initiated in September 2006 concluded in July 2010 with delivery of the hydrogen energy station to the Orange County Sanitation District demonstration site.

The full system was fabricated and installed at FuelCell Energy's facility in Danbury, CT for a complete system check and validation of performance on natural gas. Following this shop test, the system was shipped to the host site in California for operation under Phase 4 of the DOE program on both natural gas and anaerobic digester gas. As part of the contractual process to align the DOE program with the award from the California Air Resources Board (CARB), modifications to the cooperative agreement between DOE and Air Products were necessary. On 30 September 2009, Air Products received a modification which provides authorization and funding for DOE's share of activities related to 1) the design and procurement of the ADG cleanup skid, and 2) the design, procurement and operation of the hydrogen fueling station at the Orange County Sanitation District site.

\subsubsection{Process Description}

A process flow diagram of the "Fuel Treatment" and "Energy Station" blocks is provided in Figure 9. An overview and description of the system is provided below.

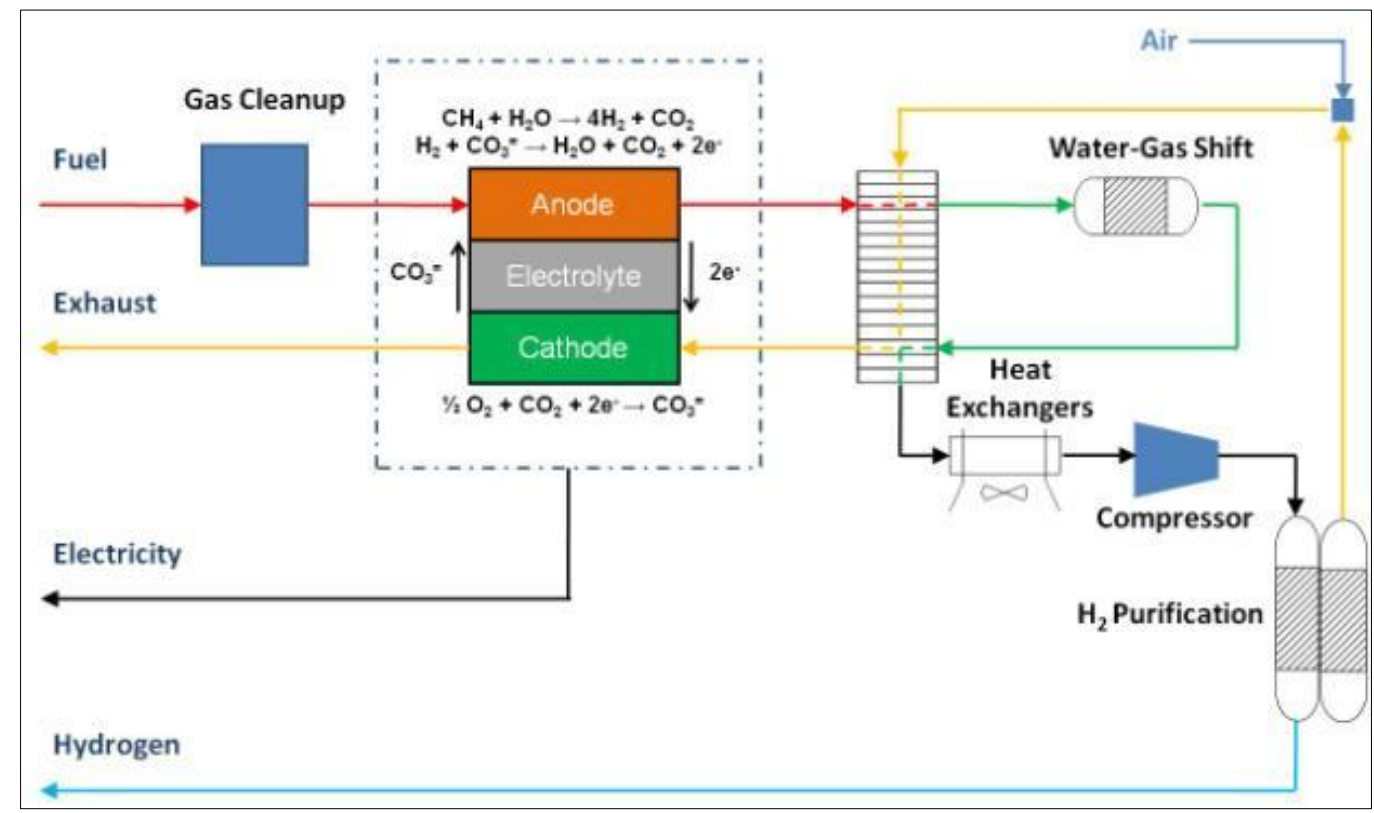

Figure 9. Detailed process flow diagram for the hydrogen energy station. 


\section{Fuel Cell Energy Station Technology Overview}

The hydrogen energy station consists of an anaerobic digester gas clean-up skid and a FuelCell Energy DFC300R MA molten carbonate fuel cell (the "fuel cell"). The fuel cell is a hightemperature, high-efficiency stationary fuel cell that offers significant benefits over conventional energy technologies. The fuel cell is capable of generating electricity directly from a hydrocarbon fuel, such as natural gas and digester gas, by reforming the fuel internally to produce power, process heat and hydrogen-containing syngas. Of the 65+ DFC fuel cells operating worldwide, 10 are operating on anaerobic digester gas (ADG) and seven are operating at wastewater treatment plants. Data for $>5,000$ hours of operation are available for several systems.

This one-step process significantly reduces costs while maximizing electrical efficiency. In addition, DFC ${ }^{\circledR}$ power plants generate high-quality, by-product heat energy $\left(700^{\circ} \mathrm{F}\right)$ that can be harnessed for combined heat and power (CHP) applications. DFC ${ }^{\circledR}$ power plants provide an electrical efficiency of $47 \%$, and up to $70 \%$ energy efficiency in CHP applications.

Electricity generated by the fuel cell energy station will be put into plant equipment, and thermal energy recovered from the fuel cell will be used to provide heat for the digester process. In addition to electricity and thermal energy, the DFC300MA fuel cell is specially modified to produce a hydrogen-enriched anode gas stream discussed below.

\section{Digester Gas Clean-up}

The following equipment was provided under Cooperative Agreement DE-FC36-05G085026. However, due to the direct impact of the contaminant removal system on the performance of the fuel cell stack, a description is provided here.

Anaerobic digester gas (ADG) contains contaminants that must be removed before the ADG can be used as a fuel source for generating syngas. It is difficult to remove these contaminants, which include siloxanes, hydrogen sulfide, methanol and ammonia. Siloxanes are a family of chemical compounds also known as organosilicons that can seriously damage all forms of generation systems. Widely used in toiletries and cosmetics, siloxanes find their way into municipal wastewater streams and are not broken down during the anaerobic digestion process. Subsequently, the fuel cell power plants operating on ADG require a fuel treatment system that typically uses graphite carbon-based filter media with pore structures specially designed to remove siloxanes. In conjunction with this pre-treatment method, hydrogen sulfide $\left(\mathrm{H}_{2} \mathrm{~S}\right)$ is also extracted using a catalytic iron sponge system. Residual oxygen is removed by either a carbon bed or a deoxidizer reactor, depending on the specific ADG analysis. Other methods are used to eliminate ammonia, methanol and excess humidity from the ADG stream.

\section{Direct Fuel Cell Unit}

The fuel gas from the ADG clean-up skid is fed into the DFC ${ }^{\circledR}$ unit. Methane in the digester gas is internally reformed at the fuel cell anode to hydrogen and $\mathrm{CO}_{2}$ via the following reaction:

$$
\mathrm{CH}_{4}+\mathrm{H}_{2} \mathrm{O} \rightarrow 4 \mathrm{H}_{2}+\mathrm{CO}_{2} \text { (+ by-product } \mathrm{CO} \text { ) }
$$

Some of the hydrogen is converted to power, and some remains available for recovery. The $\mathrm{CO}_{3}^{-2}$ comes from the cathode via the electrolyte, described below:

$$
\mathrm{H}_{2}+\mathrm{CO}_{3}^{-2} \rightarrow \mathrm{H}_{2} \mathrm{O}+\mathrm{CO}_{2}+2 \mathrm{e}^{-} \text {(power) }
$$

The fuel cell operates near $600^{\circ} \mathrm{C}$ and uses a molten carbonate electrolyte as the charge carrier. The fuel cell stack generates a DC voltage, which is then converted to AC by an 
inverter on the electrical skid (E-BOP). The system produces $480 \mathrm{VAC}, 60 \mathrm{HZ}, 300 \mathrm{~kW}$ (nominal).

Heated air is combined with the waste gas from the hydrogen purification system and combusted. These waste combustion gases are fed to the fuel cell cathode, which converts waste gas $\mathrm{CO}_{2}$ to the energy carrier $\left(\mathrm{CO}_{3}{ }^{-2}\right)$ to complete the fuel cell circuit:

$$
1 / 2 \mathrm{O}_{2}+\mathrm{CO}_{2}+2 \mathrm{e}^{-} \rightarrow \mathrm{CO}_{3}^{-2}
$$

Excess $\mathrm{CO}_{2}$ and water leave the cathode as exhaust. Heat is recovered from these exhaust gases using cooling water, which can be provided to the digester facility for use as heating water.

\section{Syngas Conditioning}

The DFC ${ }^{\circledR}$ unit produces a hydrogen-rich gas stream at the anode. The off-gas from the anode contains hydrogen, by-product $\mathrm{CO}, \mathrm{CO}_{2}$ and $\mathrm{H}_{2} \mathrm{O}$, a combination commonly called syngas. The syngas is sent to the anode cooling skid (also called the $A / E$ cooling skid), where it is cooled to $300^{\circ} \mathrm{C}$ and fed to a water-gas-shift (WGS) catalytic reactor to convert most of the CO into $\mathrm{CO}_{2}$ and hydrogen, as follows:

$$
\mathrm{H}_{2} \mathrm{O}+\mathrm{CO} \rightarrow \mathrm{H}_{2}+\mathrm{CO}_{2}
$$

The syngas is cooled further and passed through a direct-contact aftercooler to lower the temperature, remove some of the water and eliminate contaminants. This shifted/conditioned syngas is then sent to the hydrogen purification skid.

\section{Hydrogen Purification}

During Phase 2, process design and cost information was developed using a rotary-valve pressure swing adsorption (PSA) system. As part of the detailed design phase, Air Products' Adsorption Technology Center reviewed this purification cycle and determined that a different approach was needed due to the high levels of carbon dioxide in the feed gas and requirements for high-purity product hydrogen with corresponding high recovery. Alternative cycles were first evaluated using in-house simulation methods and then tested in the laboratory. These utilized high-pressure feed gas (300 psig) and resulted in modest hydrogen recoveries of $75 \%$.

New process cycles were then simulated and evaluated in the same manner, and resulting in an improved process design. This improved cycle required a feed pressure of only 100 psig, resulting in higher system efficiency (due to less parasitic power consumption for $\mathrm{H}_{2}$ production) while increasing expected hydrogen recovery to $85 \%$. A fuel cell can be damaged from pressure spikes in the hydrogen purification system, but the new cycle reduces this risk because of the lower operating pressure ( 1 psi). This improved cycle led to the awarding of US patent 7,695,545.

In the as-built system, the hydrogen purification system first chills the shifted syngas by $55^{\circ} \mathrm{C}$, and water is removed with a condensate separator. The syngas is then compressed to 150 psig by a variable-frequency, drive-controlled compressor. Each stage of compression has coolers and condensate separators. The compressed gas is fed to the pressure swing adsorption (PSA) system, which uses adsorbents to remove contaminants like carbon monoxide (CO) and carbon dioxide $\left(\mathrm{CO}_{2}\right)$ to the required levels. This hydrogen is then compressed for use. The PSA waste gas ( $\mathrm{CO}, \mathrm{CO}_{2}, \mathrm{H}_{2} \mathrm{O}$ and unconverted methane) is returned to the cathode side of the fuel cell to complete the electrical circuit. A pressure fluctuation suppression system protects the fuel cell from possible pressure surges from the purifier. 
The product hydrogen either supplies the hydrogen fueling equipment or is returned to the fuel cell for reprocessing. The PSA system can also be placed in stand-by mode to stop hydrogen production when the downstream storage equipment is full, allowing for maximum power production by the DFC system and improved system efficiency and economics.

\subsubsection{Timetable and Design Highlights}

Table 3 provides a list of major highlights associated with the performance of work at the end of Phase 2 and all of Phase 3. Some key deliverables are provided below.

Table 3. Schedule of engineering activities under Phases 2 and 3.

\begin{tabular}{|c|c|c|c|}
\hline Milestone & $\begin{array}{c}\text { Anticipated } \\
\text { Date Based on } \\
\text { Phase } 2 \text { Design } \\
\text { Basis }\end{array}$ & $\begin{array}{c}\text { Actual Date } \\
\text { Following } \\
\text { Phase } 3 \\
\text { Detailed } \\
\text { Design }\end{array}$ & Comments \\
\hline Complete Critical Component Testing & $3 / 31 / 06$ & $3 / 31 / 06$ & \\
\hline $\begin{array}{l}\text { Select Demonstration Site (including } \\
\text { switch to renewable hydrogen }+ \\
\text { power production) }\end{array}$ & $12 / 31 / 05$ & $2 / 15 / 07$ & $\begin{array}{l}\text { Changed } \\
\text { program to } \\
\text { renewable } \\
\text { feedstock }\end{array}$ \\
\hline $\begin{array}{l}\text { Revise cost estimates based upon } \\
\text { Phase } 2 \text { Preliminary Design and } \\
\text { submit Continuation Application }\end{array}$ & $2 / 1 / 06$ & $4 / 4 / 06$ & $\begin{array}{l}\text { Cost increases } \\
\text { identified }\end{array}$ \\
\hline Complete engineering specifications & $3 / 30 / 07$ & $3 / 31 / 08$ & \\
\hline $\begin{array}{c}\text { Specify and order syngas compressor } \\
\text { skid }\end{array}$ & $9 / 30 / 06$ & $1 / 1 / 08$ & \\
\hline Complete system Hazop review & $12 / 31 / 06$ & $3 / 5 / 09$ & \\
\hline Complete detailed design & $3 / 31 / 07$ & $3 / 31 / 08$ & \\
\hline $\begin{array}{c}\text { Specify and order balance of } \\
\text { equipment }\end{array}$ & $3 / 31 / 07$ & $8 / 31 / 08$ & $\begin{array}{l}\text { CARB selection } \\
\text { June } 2008\end{array}$ \\
\hline $\begin{array}{l}\text { Develop plan for lab test at FuelCell } \\
\text { Energy's facilities }\end{array}$ & $6 / 30 / 07$ & $2 / 27 / 09$ & \\
\hline $\begin{array}{c}\text { Start shop validation test at FuelCell } \\
\text { Energy }\end{array}$ & $6 / 30 / 07$ & 3/1/09 & \\
\hline $\begin{array}{l}\text { Complete shop validation test at } \\
\text { FuelCell Energy (including full } \\
\text { automation for unattended operation) }\end{array}$ & $9 / 30 / 07$ & $12 / 31 / 09$ & $\begin{array}{l}\text { Shipped to } \\
\text { OCSD June } \\
2010\end{array}$ \\
\hline
\end{tabular}

FuelCell Energy focused its early efforts on extracting hydrogen-containing gas from the fuel cell anode and determining related impacts on system operation (for example, changes to the flow profile within the fuel cell stack arrangement). This work also investigated various methods to filter the electrolyte from the extracted gas and return it to the fuel cell.

Due to the impacts of gas extraction from the anode and return of hydrogen-depleted gas to the cathode, Air Products included anode exhaust gas skid design as part of the subcontract with FuelCell Energy. Figure 10 shows the computer-aided model for the design of the system, which includes the water-gas shift, gas cooling, and controls to allow for integrated operation between this subsystem and the fuel cell. Due to the fuel cell's low operating pressure and the adverse impact of low available pressure drop on heat transfer, FuelCell Energy evaluated several cooling system designs. Figure 11 shows the direct-contact system that was ultimately selected; this configuration met the requirements for both pressure drop and temperature 
control. Significant effort was also spent on the start-up, shutdown, and operating controls related to the return of higher-pressure (100 psig) gas from the hydrogen purification system to the low-pressure cathode of the fuel cell.

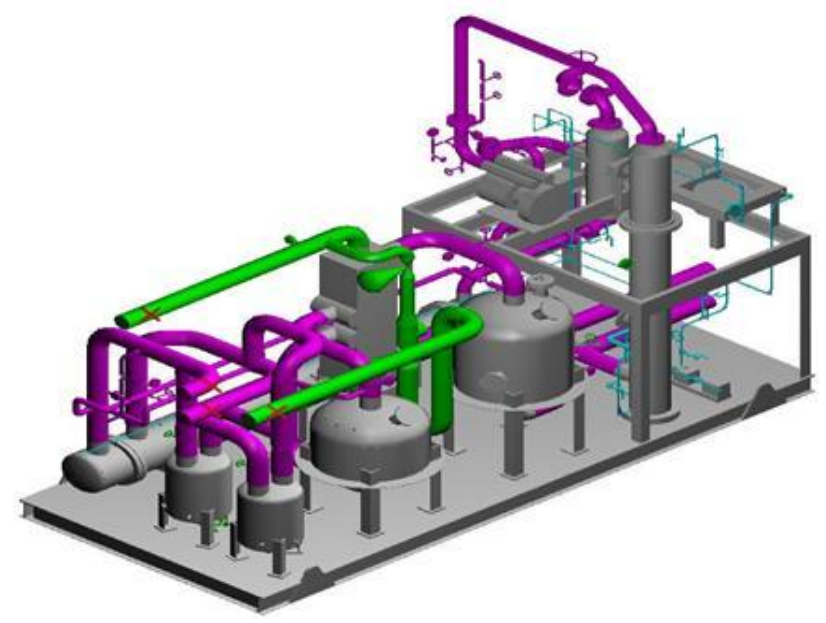

Figure 10. Computer-aided design model for the anode exhaust gas system.

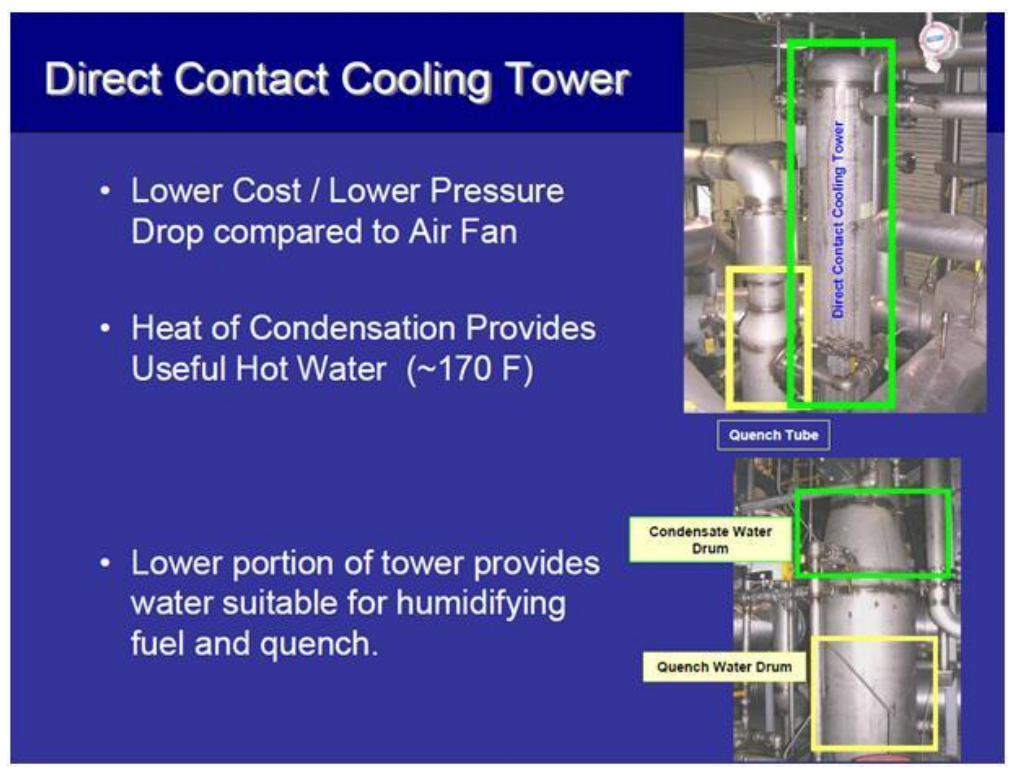

Figure 11. Cooling system within the anode exhaust gas system.

As noted in Table 3, Air Products and FuelCell Energy surveyed potential host sites with an available renewable feedstock at which to locate a demonstration facility. Discussions were initiated with the Orange County Sanitation District (OCSD), which provides water treatment services for many of the communities in Orange County, California. Additional details about the OCSD site are provided in Section 2.4.

As the project moved into the detailed design efforts of Phase 3, cost increases were identified by both Air Products and FuelCell Energy. Additional funding was provided by DOE to offset increases incurred by FuelCell Energy, and Air Products sought and was awarded additional funding by the California Air Resources Board and South Coast Air Quality Management District. 


\subsubsection{Shop Validation Testing}

The original statement of work for the project called for six months of testing to demonstrate the concept of hydrogen coproduction from a high-temperature fuel cell using natural gas as feedstock. However, with the incorporation of a renewable feedstock at the OCSD facility, system operation would need to be automated - something not envisioned during the detailed design effort. The engineering teams from Air Products and FuelCell Energy recommended that this automation work be included during the system validation test at FuelCell Energy's facilities in Danbury, CT. As part of their production method for DFC systems, FuelCell Energy conditions the fuel cell stacks prior to shipment; natural gas is available to supply the fuel cell, and generated power can be utilized either within FuelCell Energy's facilities or exported to the local utility. Due to the first-of-its-kind nature of this project, the team decided that operating close to FuelCell Energy's engineering and maintenance resources would be critical to the success of any testing. In addition, Air Products' engineers could be brought to the site to operate the hydrogen compression and purification equipment.

The fuel cell system was initially installed at FuelCell Energy's facilities during the summer of 2008. Figure 12 shows the fuel cell and mechanical balance of plant (MBOP) of the DFC system. Due to space limitations, fuel cell components were installed within an engineering laboratory, with the balance of the equipment located outside of the building.

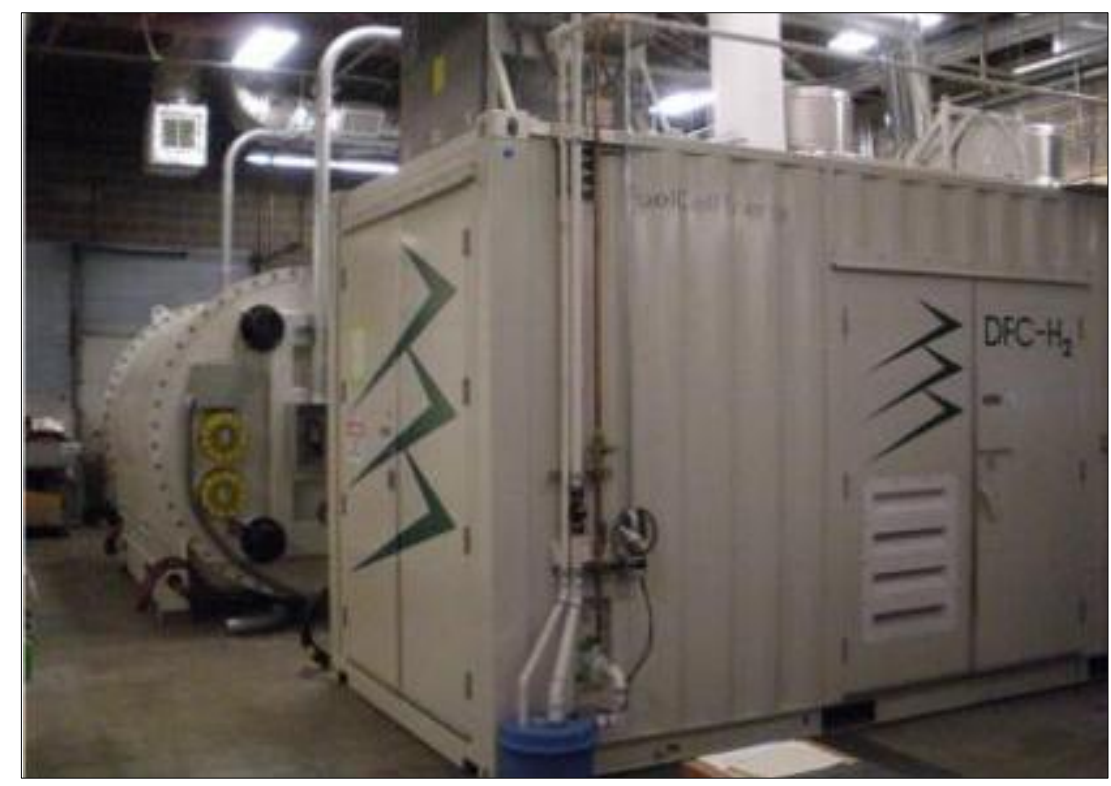

Figure 12. FuelCell Energy DFC-300 and mechanical balance of plant (MBOP).

One of the major innovations accomplished during design of the hydrogen energy station was a method to extract gas from the anode that would not impact the operation of the reformer or fuel cell stack. Figure 13 shows the new piping configuration, designed by FuelCell Energy, which extracts gas from the anode. 

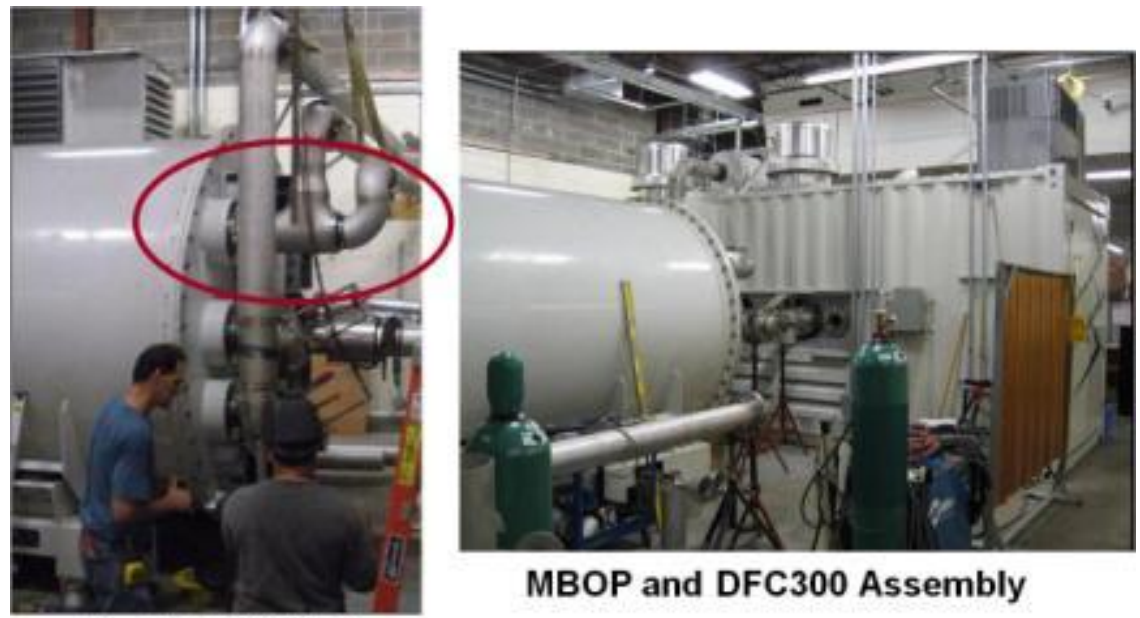

MBOP and DFC300 Assembly

\section{$\mathrm{H}_{2}$ Ready Piping}

Figure 13. Hydrogen extraction from the DFC-300 module.

Gas from the anode is then sent to the anode exhaust gas skid (also called the " $\mathrm{H}_{2}$ booster") where the water-gas shift and heat exchangers are installed. Products from the system are the hydrogen-upgraded gas stream and condensed water, with the latter being recycled to the fuel cell. As shown in Figure 14, the anode exhaust gas skid is located outside of the building along with the fuel cell. All exterior equipment was installed on concrete blocks that maintained an elevation above the area flood plain while providing the proper strength and stability needed for system operation.

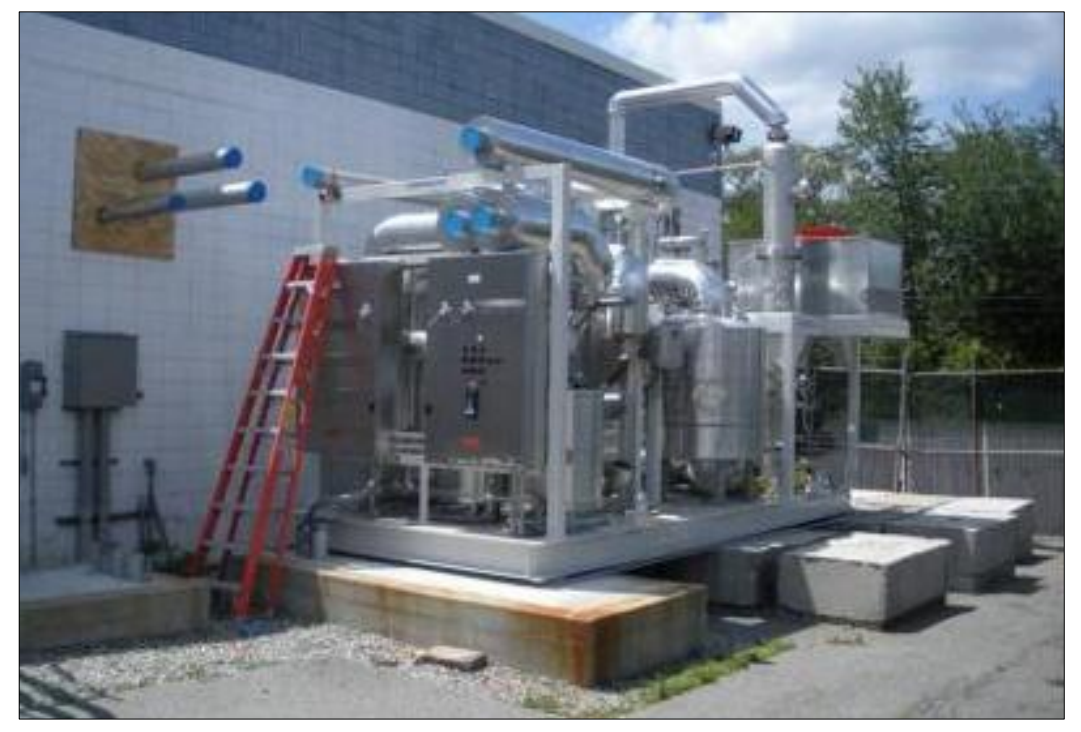

Figure 14. Anode exhaust gas skid at the shop validation test.

The components for the balance of the hydrogen energy station were delivered and installed during the winter of 2008-09. The treated anode exhaust gas is then compressed to the inlet pressure required for separation. The compression system (Figure 15) utilizes two machines each rated at $60 \%$ of design flow capacity along with variable-speed motor controls. Flow disturbances, which can affect the operation of either the anode from the fuel cell or the hydrogen purification system, were taken into account as the compression system was designed and the control strategy was developed. 


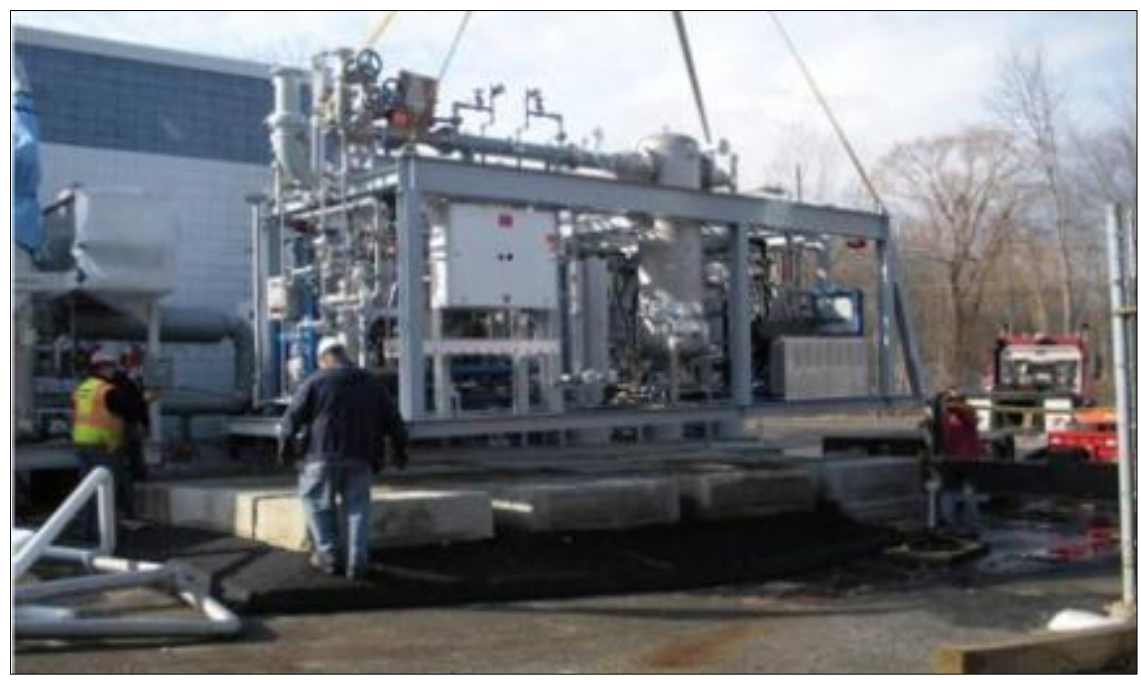

Figure 15. Hydrogen energy system compression system.

Compressed gas is then fed to the six-bed pressure swing adsorption (PSA) system. A surge tank, installed to collect the tail gas from the bed depressurization step, limits the fluctuations within the separation vessels and also evens the flow of gas being returned to the fuel cell. Figure 16 shows the PSA system installed in Danbury, CT.

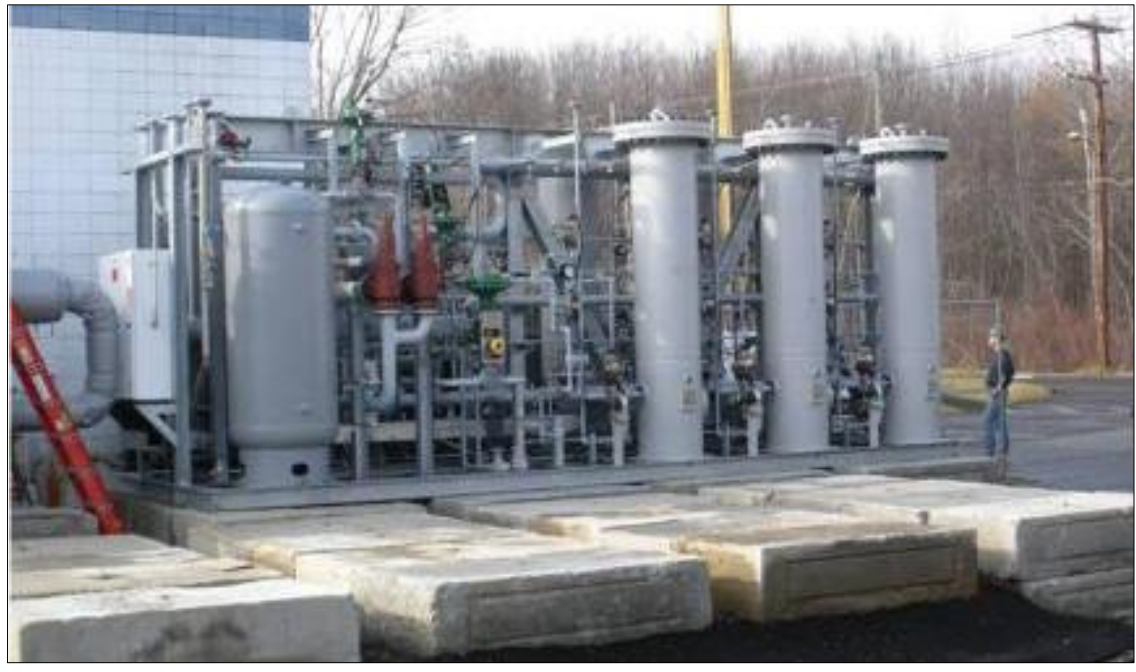

Figure 16. Pressure swing adsorption system.

The fully-installed hydrogen upgrading/compression/purification system is shown in Figure 17. The equipment arrangement and subsequent interconnecting piping between the various systems were selected to match the installation requirements at the OCSD site. Other installed items include separate mechanical and electrical support components for the major equipment. 


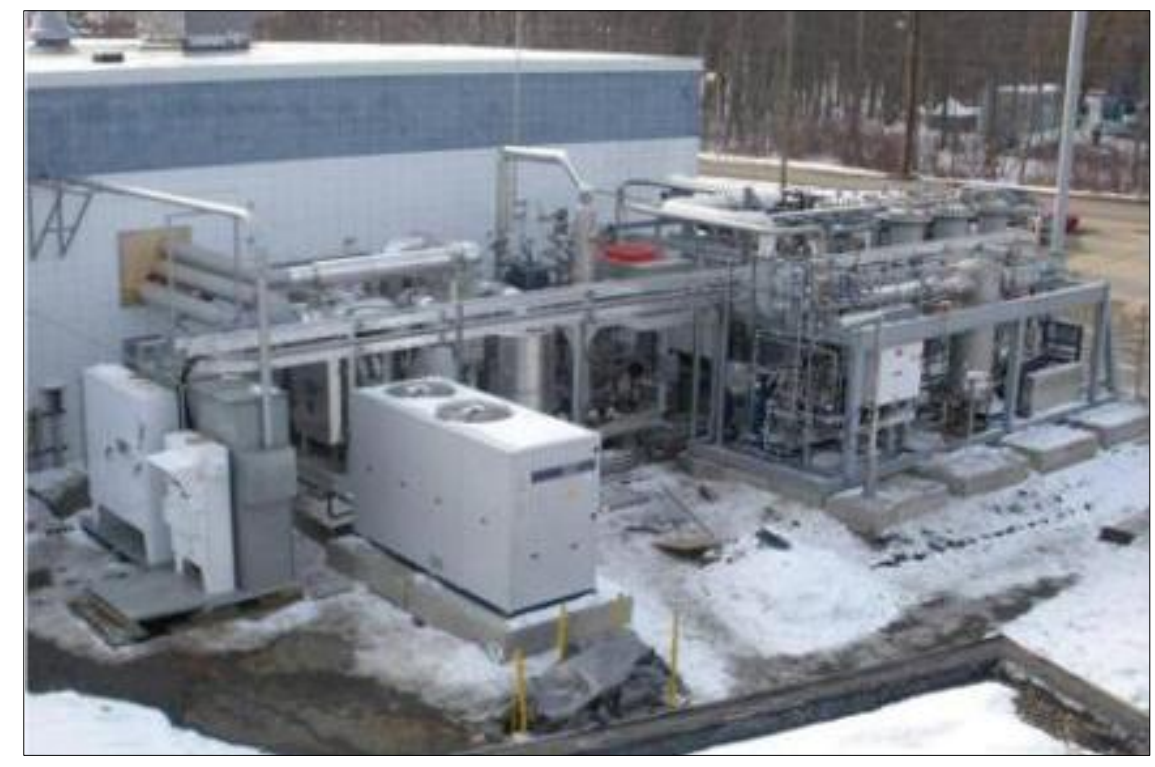

Figure 17. Hydrogen energy station installation at shop validation test.

DFC-300 operation began in late summer 2008 to test the hydrogen extraction methods and determine baseline performance of the fuel cell stack. Operation of the anode exhaust skid also commenced independently of the compression and PSA systems to validate its operating performance (e.g., system heat balance) and ability to recycle gas back to the fuel cell. Hydrogen content in the anode exhaust gas was raised from 18 volume percent (vol\%) to 29 vol\% and levels of carbon monoxide exiting the water-gas shift reactor were $<0.5 \mathrm{vol} \%$, both meeting design expectations.

Initial operation of the PSA system began in March 2009, and the system ran for about a month at $50 \%$ of the fuel cell power load. Most of the control systems between the fuel cell and PSA system were operated manually by engineers from both Air Products and FuelCell Energy to develop the operating map needed for process automation. The automated shutdown systems were validated during this period, and the pressure fluctuations detected at the fuel cell during shutdowns and other operating transients were found to be within design tolerances for the stack (a key issue during the system design phase).

Programming to automate operation of the hydrogen energy station was completed during the spring and summer of 2009, with control logic tests running from August through October. Multiple tests of the program were conducted to integrate and deintegrate 1) the PSA alone and 2) the PSA and anode exhaust gas systems from the fuel cell. The strategy for the bed pressurization/depressurization cycles for the PSA system was also finalized and validated. This strategy included operation of the fuel cell and PSA system on a simulated digester gas feed (accomplished in the absence of trace contaminants by adding carbon dioxide to the natural gas supply to the fuel cell).

Figure 18 shows a summary of the hydrogen energy station operating performance during the shop validation tests. Hydrogen production rates of 5-10 pounds per hour (corresponding to 50$110 \%$ of design) were achieved at power production rates of $200 \mathrm{~kW}$ (the interconnection with the local power company limited the power production at the Danbury facility). Carbon monoxide levels from the PSA system were consistently less than the design specification of 0.2 parts per million by volume (ppmv). 


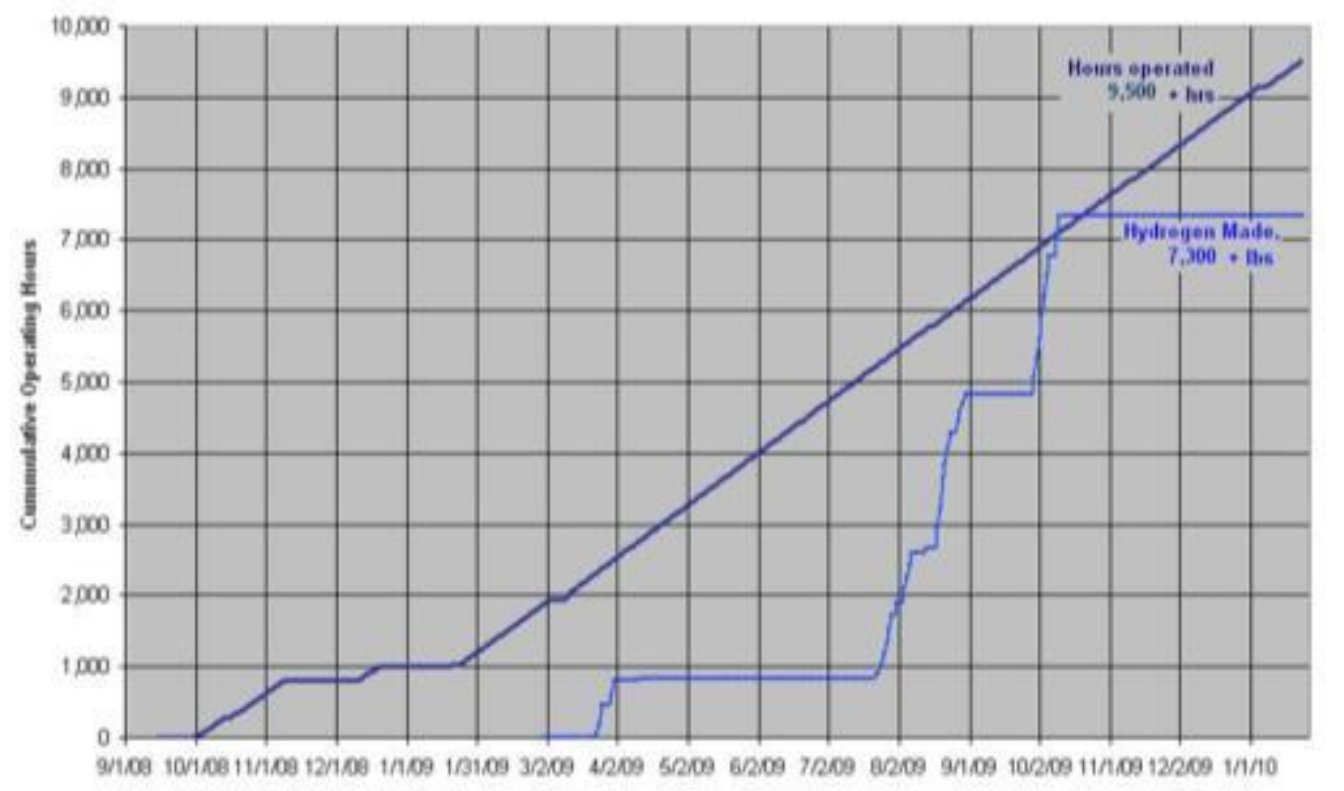

Date

ieromanomentis

Figure 18. Hydrogen energy station operating results at the shop validation test.

A snapshot from the data acquisition system showing key performance parameters for the hydrogen energy station is provided in Figure 19. Power requirements for the parasitic loads for the process were less than expected because, for much of the test work, low ambient winter temperatures in Connecticut changed the system heat balance and eliminated the need to operate a chiller to condense water upstream of the PSA feed compressor. These loads were checked during operation at OCSD (discussed further in Section 2.4).

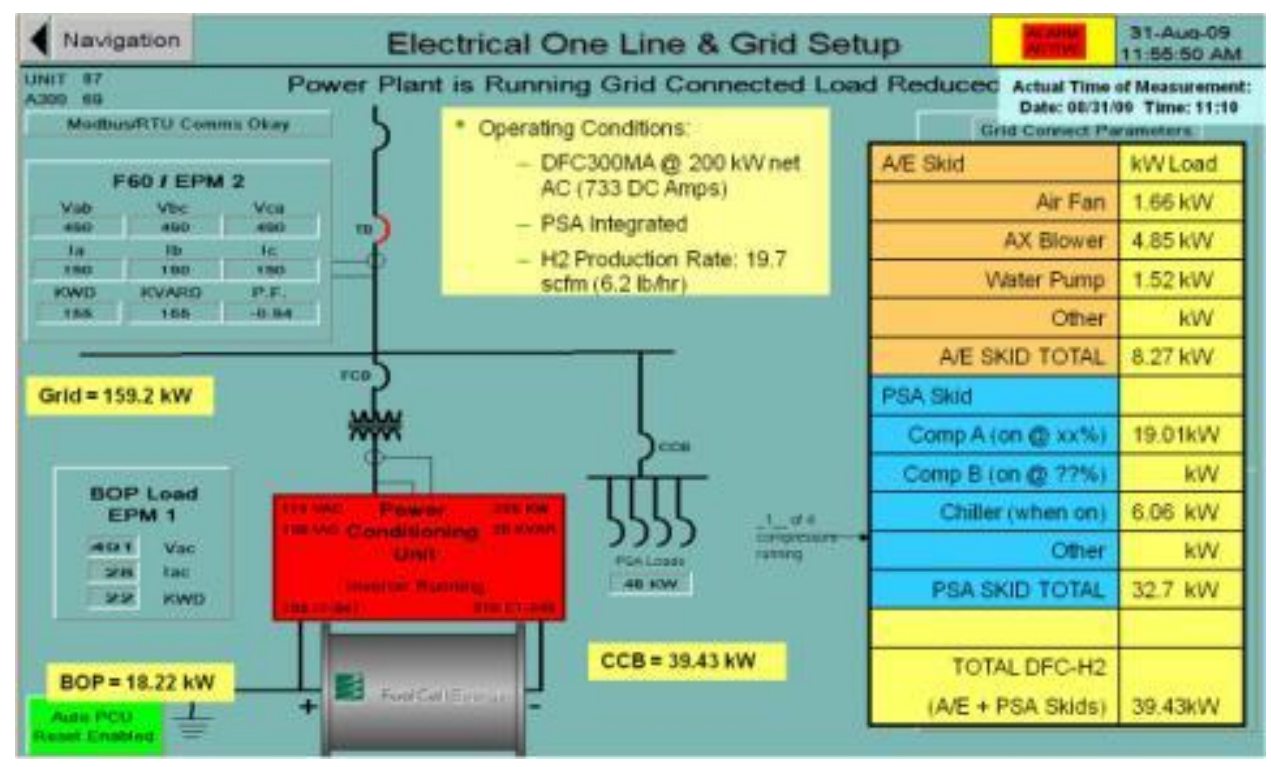

Figure 19. Snapshot of hydrogen energy station performance on 31 August 2009.

A detailed analysis of another operating period (at $3.8 \mathrm{lb} / \mathrm{hr}$ of $\mathrm{H}_{2}$ production and within power generation limits at the Danbury facility) was performed to determine the overall efficiency of the hydrogen energy station. This was found to be $54.5 \%$, using the calculation method described 
in Figure 20 and in the absence of heat recovery from the fuel cell's process exhaust. The calculated efficiency exceeds the $50 \%$ value from the system design.

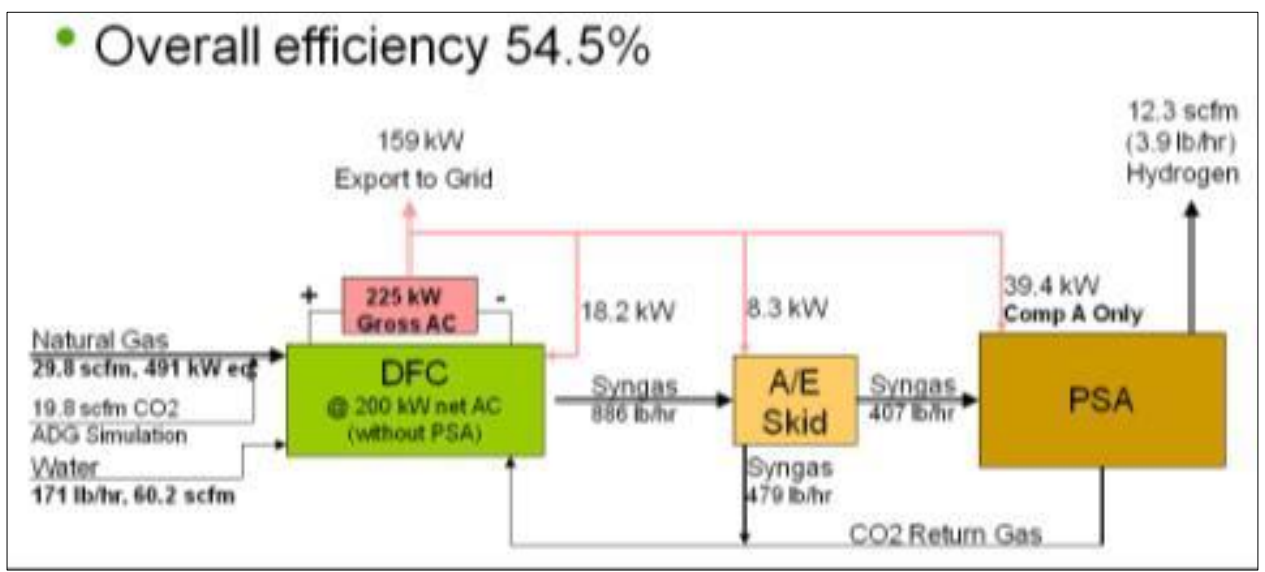

Figure 20. Hydrogen energy station overall heat and mass balance (28 August 2009).

During the shop validation test, samples of the fuel cell process exhaust (both with and without hydrogen coproduction) were taken to determine levels of carbon monoxide and nitrogen oxides. Both were detected at levels significantly below the emission limits required by the California Air Resources Board for stationary power systems (Figure 21).

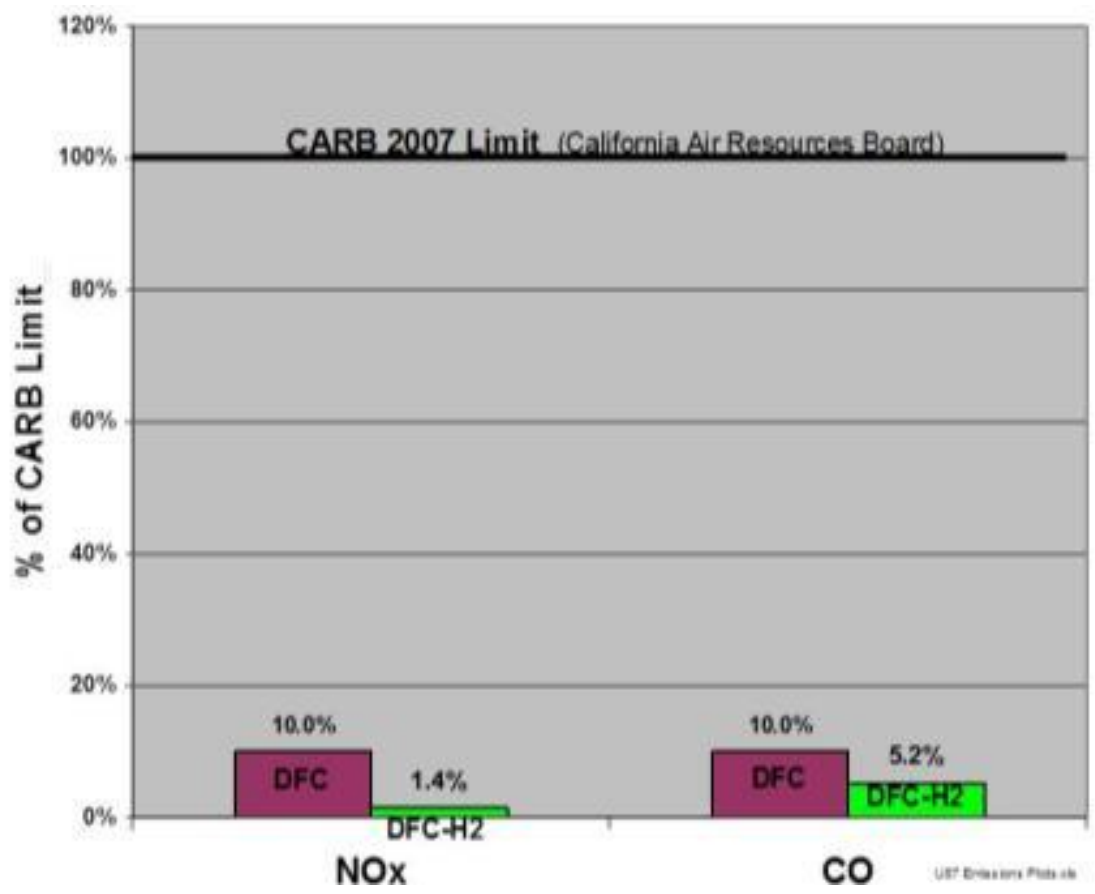

Figure 21. Hydrogen energy station emissions during shop validation testing.

Following completion of the shop validation testing, a new stack was installed for the DFC-300 fuel cell. The stack used in Danbury performed well and met its goals during the rigorous test period, but did not have adequate life remaining for three years of operation at the OCSD site in California. 


\subsection{Phase 4 - Installation, Start-up, Operation and Data Collection}

As noted earlier, Air Products began work in 2006 to identify a host site to demonstrate operation of a hydrogen energy station on a renewable feedstock instead of natural gas as originally planned. After a detailed survey of existing hydrogen consumers and availability of feedstock for the fuel cell, Air Products began negotiations with the Orange County Sanitation District (OCSD) to use one of their two waste water treatment plants that serve many communities in the Orange County, CA area. This desired site produces anaerobic digester gas which is fed to combustion engines for power generation, and $5-10 \%$ of this would be required as feedstock for the fuel cell. However, no hydrogen was used at this site.

To develop a use for hydrogen, Air Products pursued funding through 2008 solicitation from the California Air Resources Board (CARB) to 1) install and operate the hydrogen energy station, and 2) install a hydrogen refueling station in a publicly-accessible area of the OCSD complex (in fact, the hydrogen dispenser would be co-located with an existing compressed natural gas dispenser). CARB notified Air Products in June 2008 that its proposed installation at OCSD had been selected. The agreement, executed in May 2009, required an operating period of three years. Additional funding was also provided by the South Coast Air Quality Management District.

Figure 22 shows the integration of the hydrogen energy station into the OCSD wastewater treatment facility (items outside the dashed line are existing equipment items). Equipment associated with fuel treatment, hydrogen compression, storage and dispensing was part of the CARB program. DOE provided cost share toward the design and installation of this equipment under a separate Cooperative Agreement (DE-FC36-05G085026), and is not part of this program.

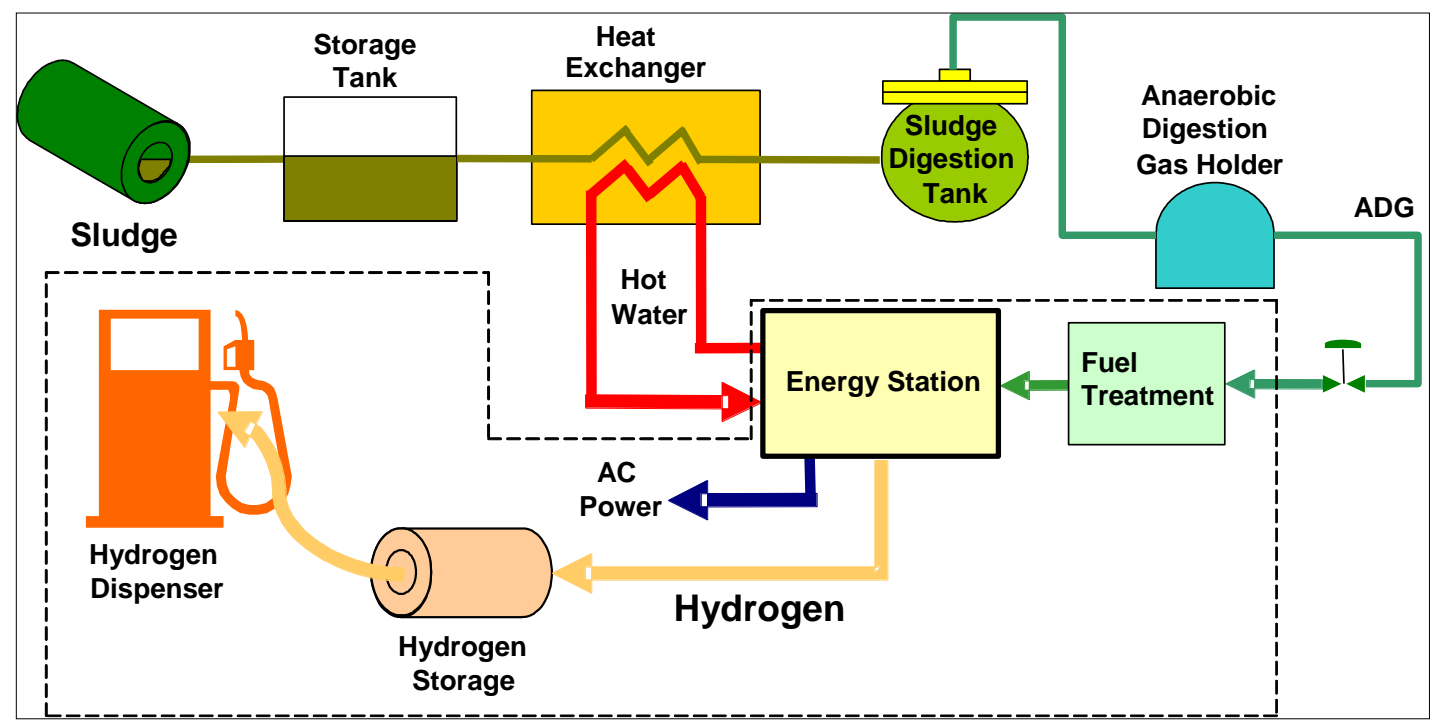

Figure 22. Overview of hydrogen production from anaerobic digester gas via the hydrogen energy station. Items outside the dashed line are existing equipment items.

The hydrogen energy station had to be integrated into the existing layout of the OCSD facility, with proximity to tie-ins for digester gas, natural gas, water and other utilities. After several iterations, Air Products and OCSD negotiated an access agreement for siting the hydrogen energy station. As shown in Figure 23, the fueling station would be located approximately 1,100 feet from the hydrogen production area. 


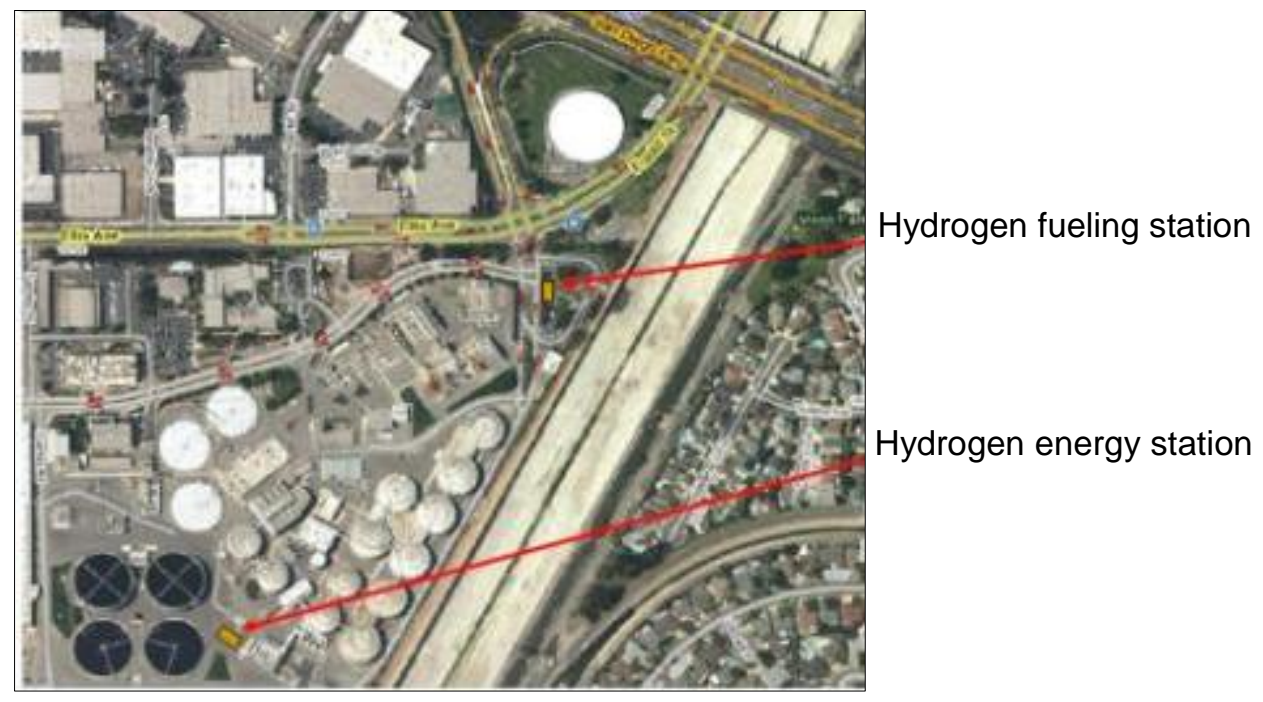

Figure 23. Relative locations of the hydrogen energy station and hydrogen fueling station.

The location for the hydrogen energy station provided adequate area to install and maintain the equipment. Figure 24 shows the layout for the hydrogen energy station, which attempted to incorporate (as much as possible) the same interconnecting piping used during the shop validation test performed under Task 2.3.

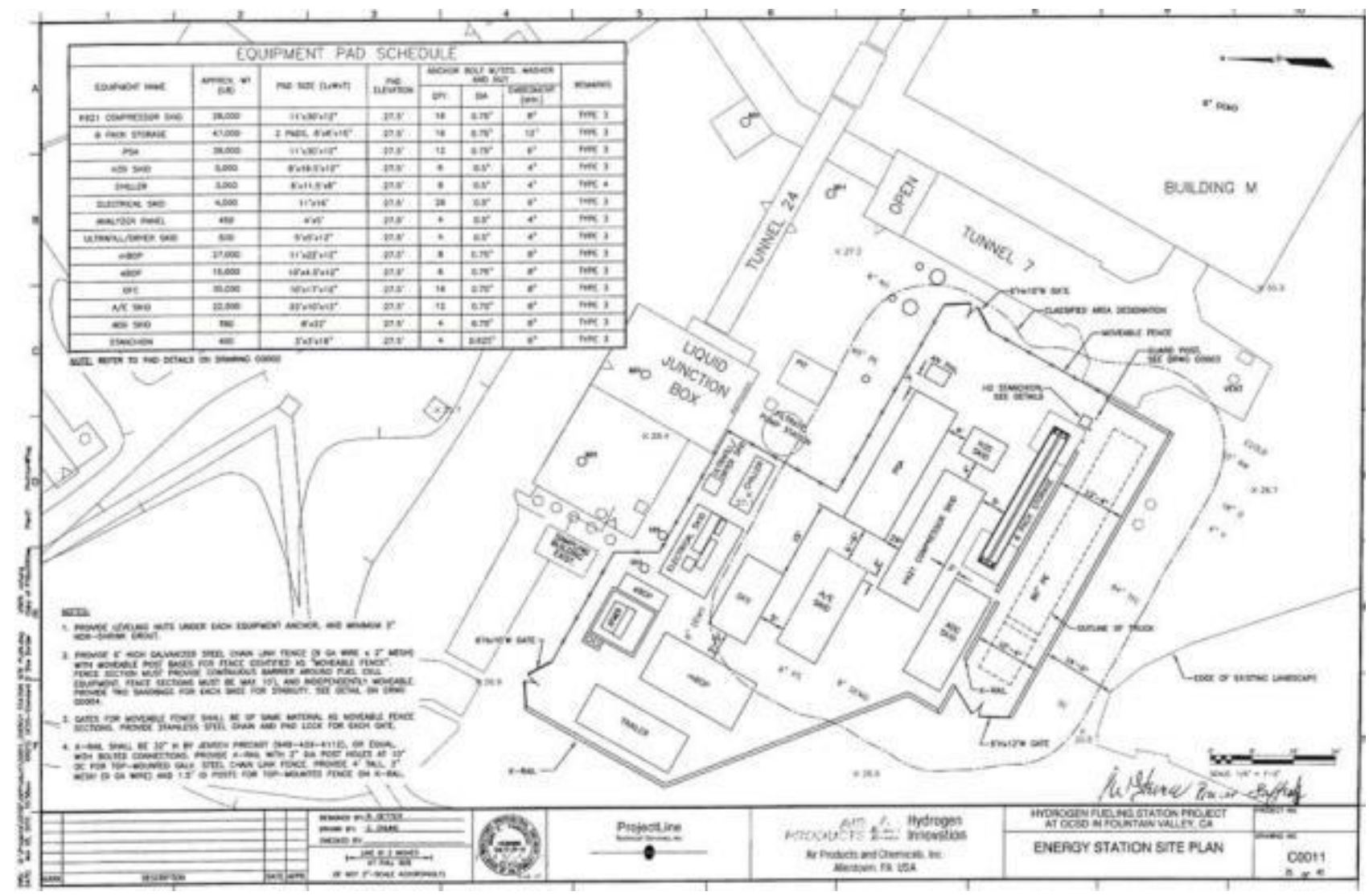

Figure 24. Layout of the hydrogen energy station at OCSD. 
The OCSD water treatment facility utilizes multiple anaerobic digesters that feed into large holding vessels, with compressors to supply the gas to the combustion engines. A tie point nearest the fuel cell was selected to supply the digester gas. The tie point location, shown in Figure 25 relative to other elements of the OCSD facility, can impact the level of trace contaminants in the ADG stream. For example, compression and cooling/condensation steps can help reduce the levels of siloxanes and other halide species in the digester gas.

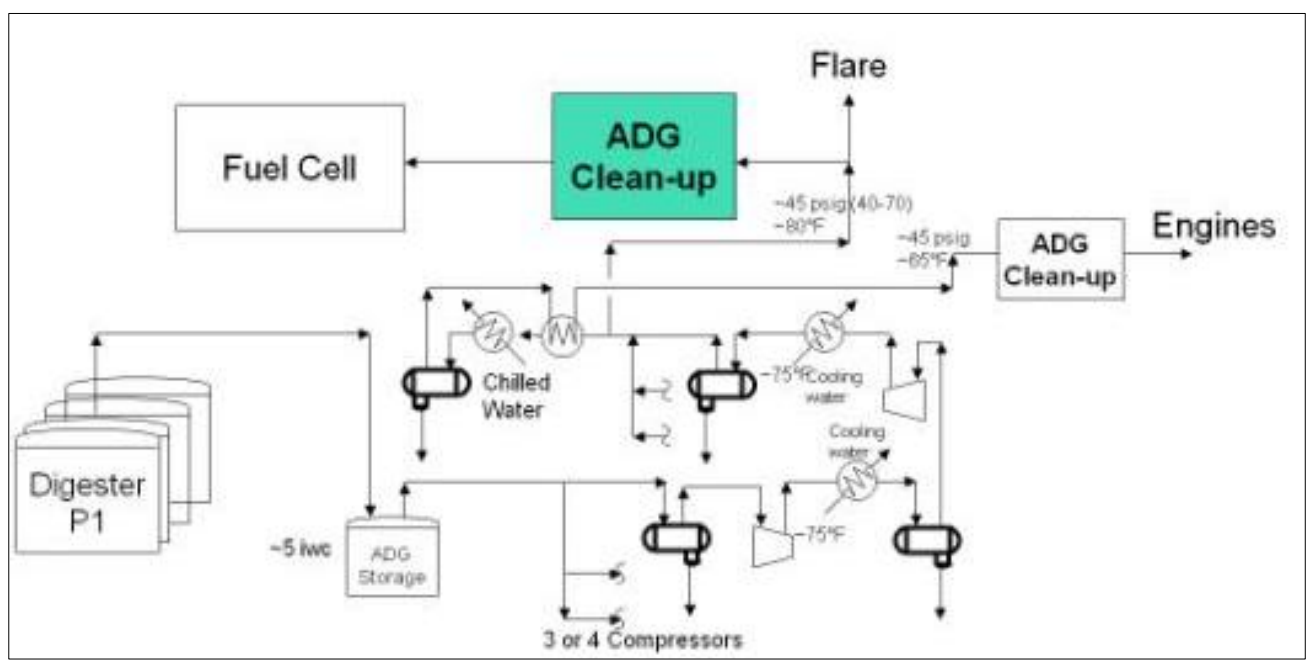

Figure 25. Process flow diagram: supply of digester gas for the hydrogen energy station.

The schedule for the overall installation at OCSD, including work on the related hydrogen fueling station provided as part of Cooperative Agreement No. DE-FC36-05G085026, entitled "California Hydrogen Infrastructure Project, is provided in Table 4. 
Table 4. Schedule of installation at OCSD.

\begin{tabular}{|l|l|}
\hline \multicolumn{1}{|c|}{ ITEM } & \multicolumn{1}{c|}{ DUE DATE } \\
\hline Hydrogen Energy Station: & \multicolumn{1}{c|}{} \\
\hline Permitting & Completed 19 February 2009 \\
\hline Facility Engineering & Completed 15 December 2008 \\
\hline Preliminary Site Surveys & Completed 21 September 2009 \\
\hline Site Preparation & Completed 18 June 2010 \\
\hline Complete Pad and Underground Utilities & Completed 01 July 2010 \\
\hline Inspection & Completed 01 July 2010 \\
\hline Equipment Siting & Completed 09 July 2010 \\
\hline Testing & Completed 25 August 2010 \\
\hline Hydrogen Fueling Station: & \\
\hline Permitting & Completed 04 August 2009 \\
\hline Facility Engineering & Completed 31 March 2010 \\
\hline Preliminary Site Surveys & Completed 21 September 2009 \\
\hline Site Preparation & Completed 06 August 2010 \\
\hline Complete Pad and Underground Utilities & Completed 03 September 2010 \\
\hline Inspection & Completed 08 September 2010 \\
\hline Equipment Siting & $\begin{array}{l}\text { Completed 11 September 2010 (high-pressure } \\
\text { tubes installed 09 November 2010) }\end{array}$ \\
\hline Testing & 09 March 2011 \\
\hline Other Related Events & \\
\hline Station Startup & 01 June 2011 \\
\hline Education/Outreach & 01 January 2010 - 31 May 2014 \\
\hline
\end{tabular}

Following completion of site work (foundations, electrical tie-ins, etc.) at OCSD, delivery of the hydrogen energy station equipment from Danbury, CT began on 8 July 2010 . Figures 26 through 29 show the installation of the various equipment skids. All required utilities (natural gas, water, power, and ADG) were tied into the system. Figure 30 shows the completion of the hydrogen energy station installation prior to commissioning at OCSD. The ADG clean-up system was not available until May 2011, so natural gas was used to begin the operating phase of the project.

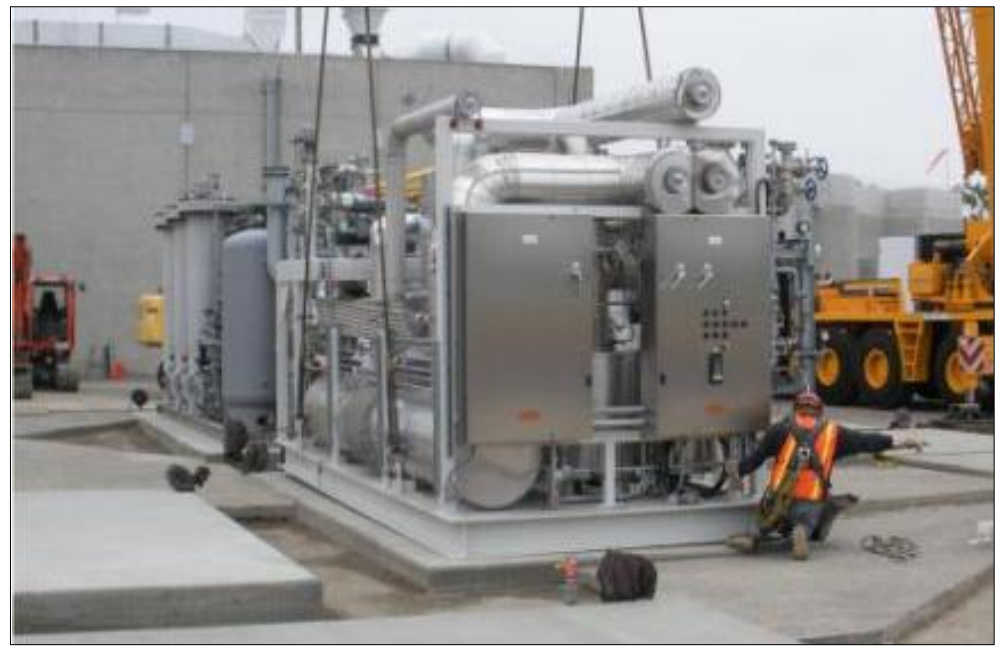

Figure 26. Installation of the anode exhaust gas skid at OCSD. 


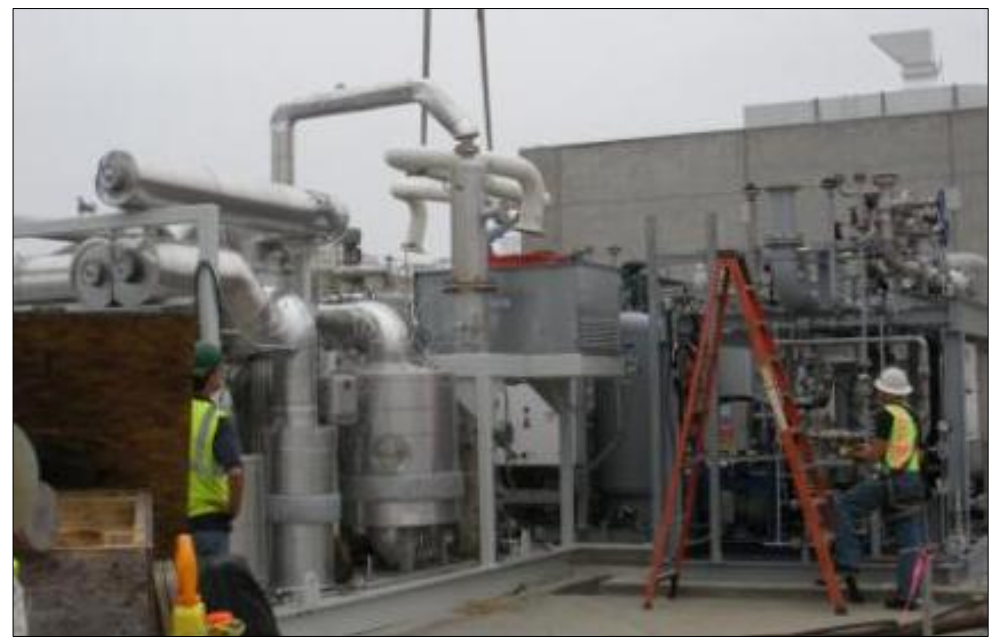

Figure 27. Installation of interconnecting piping between the DFC-300 and pressure swing adsorption system at OCSD (ground level).

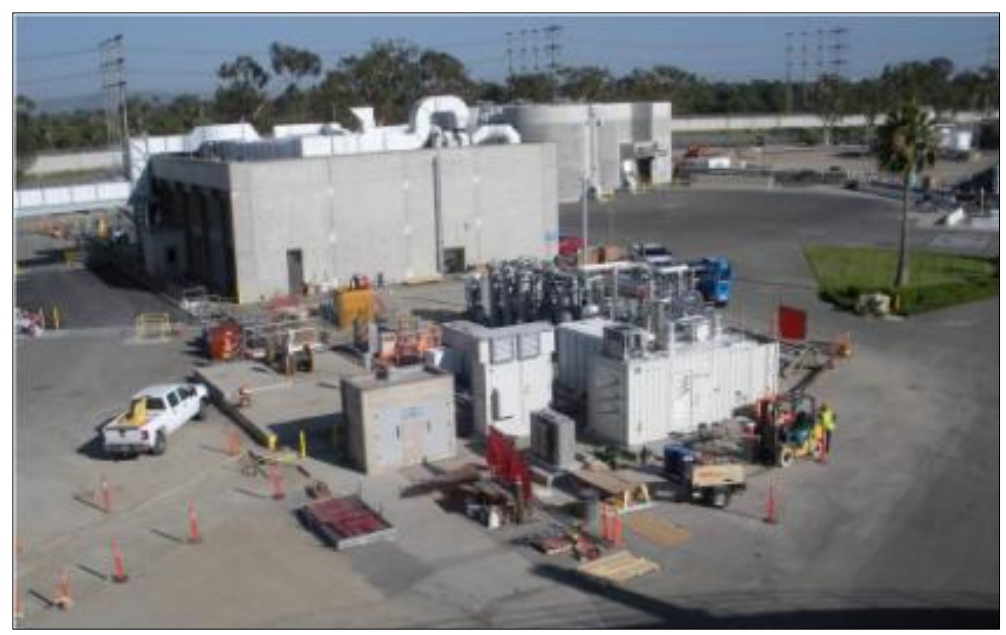

Figure 28. Installation of interconnecting piping between the DFC-300 and pressure swing adsorption system at OCSD (from above).

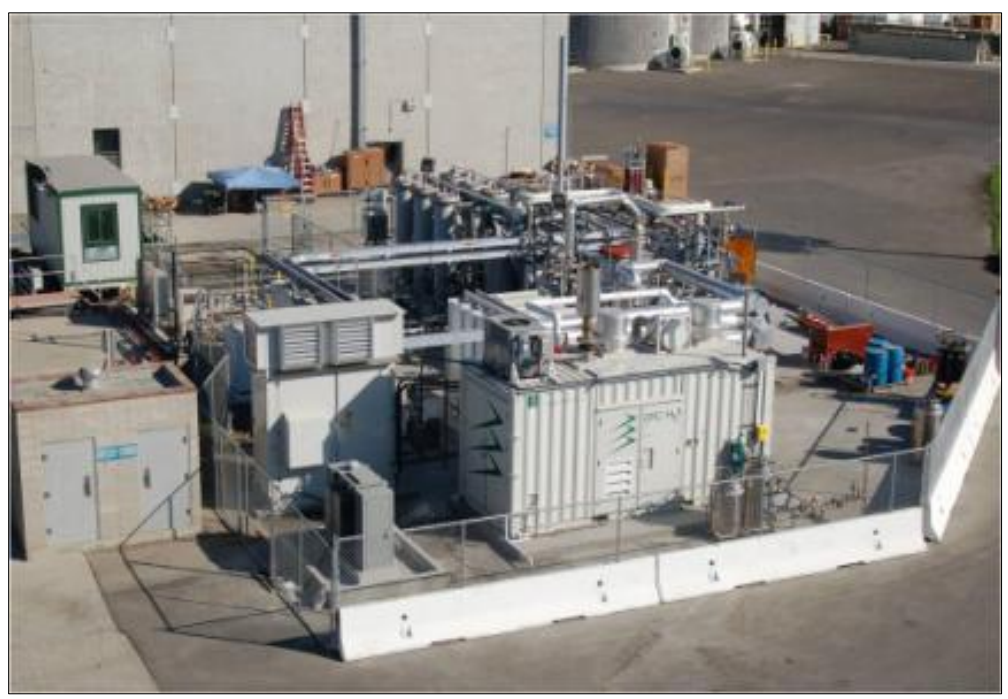

Figure 29. Installation progress at OCSD. The fuel cell is in the foreground; the pressure swing adsorption system is in the background. 


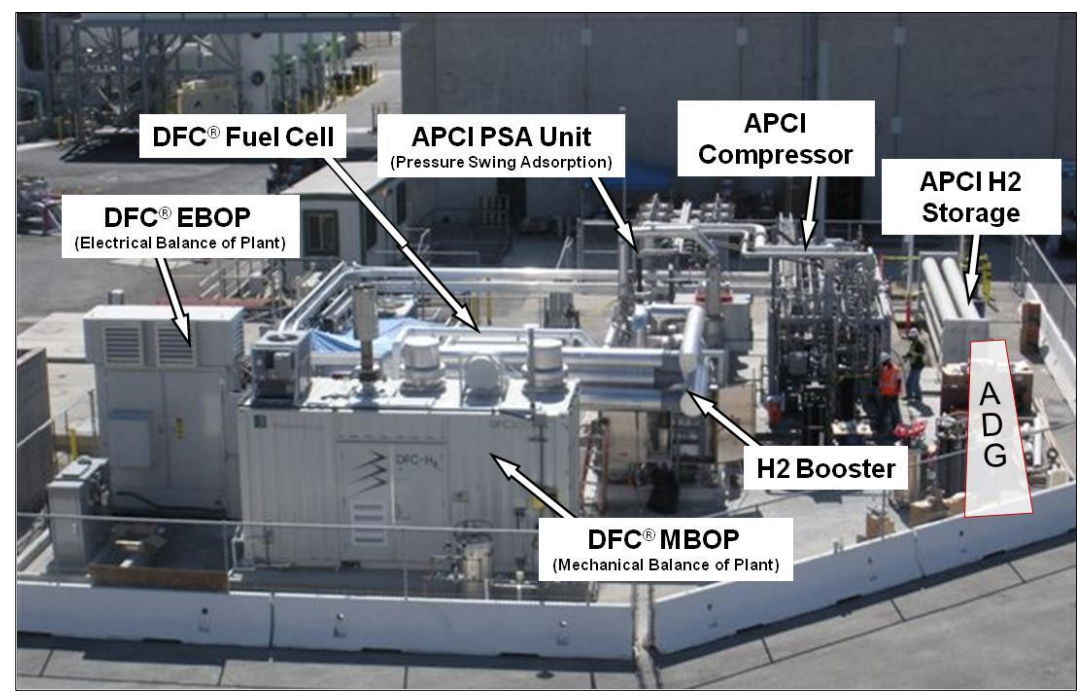

Figure 30. Installation at OCSD (24 August 2010). Future location of ADG clean-up system is indicated in lower right corner.

During the installation work, the operating teams from OCSD, Air Products, FuelCell Energy, and UC Irvine held multiple meetings to coordinate site activities during construction and plan for system operation.

After completing commissioning activities such as leak checking and system purging with nitrogen, initial operation of the DFC-300 system on natural gas began on 13 September 2010 . The following initial results were realized:

- Initial power operations were achieved. This included power conditioning of the fuel cell that resulted in a power output increase of $40 \mathrm{~kW} /$ day for seven days, reaching $300 \mathrm{~kW}$ net AC on 20 September 2010. Excess power was exported to the OCSD power grid.

- Following initial power operation, the water-gas shift, water removal and PSA feed compressor systems were placed into service.

- Initial integration with the PSA system at a 50\% feed gas rate occurred on 23 September 2010. The system tripped shortly after integration, demonstrating the performance of the deintegration process in the field.

During October and November 2010, the fuel cell was operated at various loads on natural gas, and the hydrogen purification system was operated periodically to test the integration/deintegration of the two systems. During this initial operating period, the power conditioning unit (PCU/inverter) associated with the fuel cell showed unusual behavior in its ability to connect with the local grid. Experts from FuelCell Energy characterized the grid quality and identified power conditioning system changes required to match the highly-inductive power factor $(0.6$ to 0.8$)$ with larger voltage sags (5-10\%). Troubleshooting efforts began in early December. On 14 December, a module within the inverter was damaged by an electrical fault.

Figure 31 shows the initial operating results for the hydrogen energy station at OCSD. Over 1,000 hours of operation in power and power-plus-hydrogen modes were completed from startup through 31 December 2010. From January to March 2011, the inverter was repaired, and the fuel cell operated for one month at $100 \mathrm{~kW}$ power output and another at $200 \mathrm{~kW}$ power output. Total on-stream power production was $93.4 \%$ (excluding inverter repair time). Hydrogen quality was also checked and met all performance specifications. Hydrogen was vented locally pending commissioning of the hydrogen refueling station. 


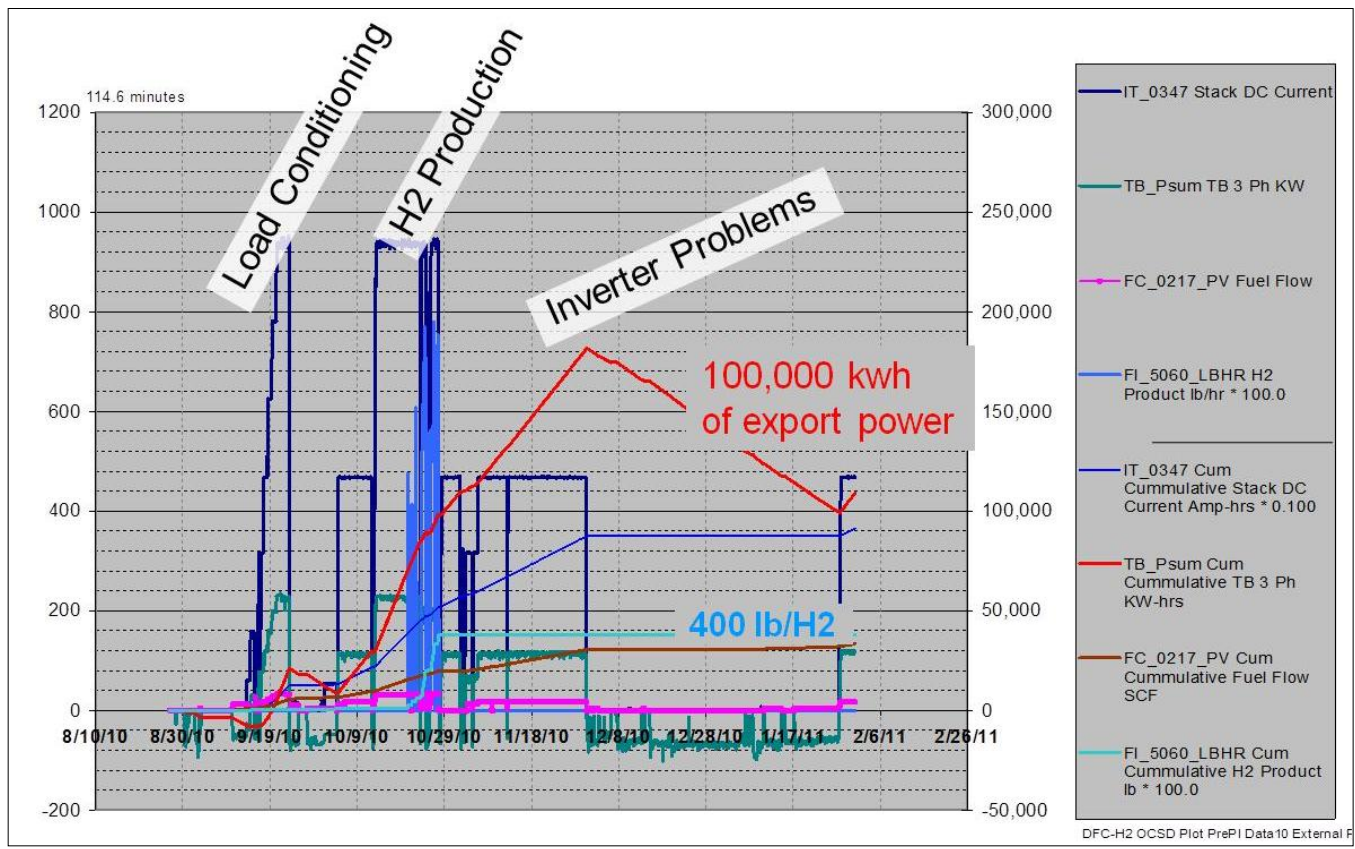

Figure 31. Operating results from the hydrogen energy station at OCSD, Sept. 2010-Feb. 2011.

Figure 32 shows the results of a heat and material balance for October 2010 operations. An overall efficiency of $54.2 \%$ was calculated, which exceed the $50 \%$ DOE program target.

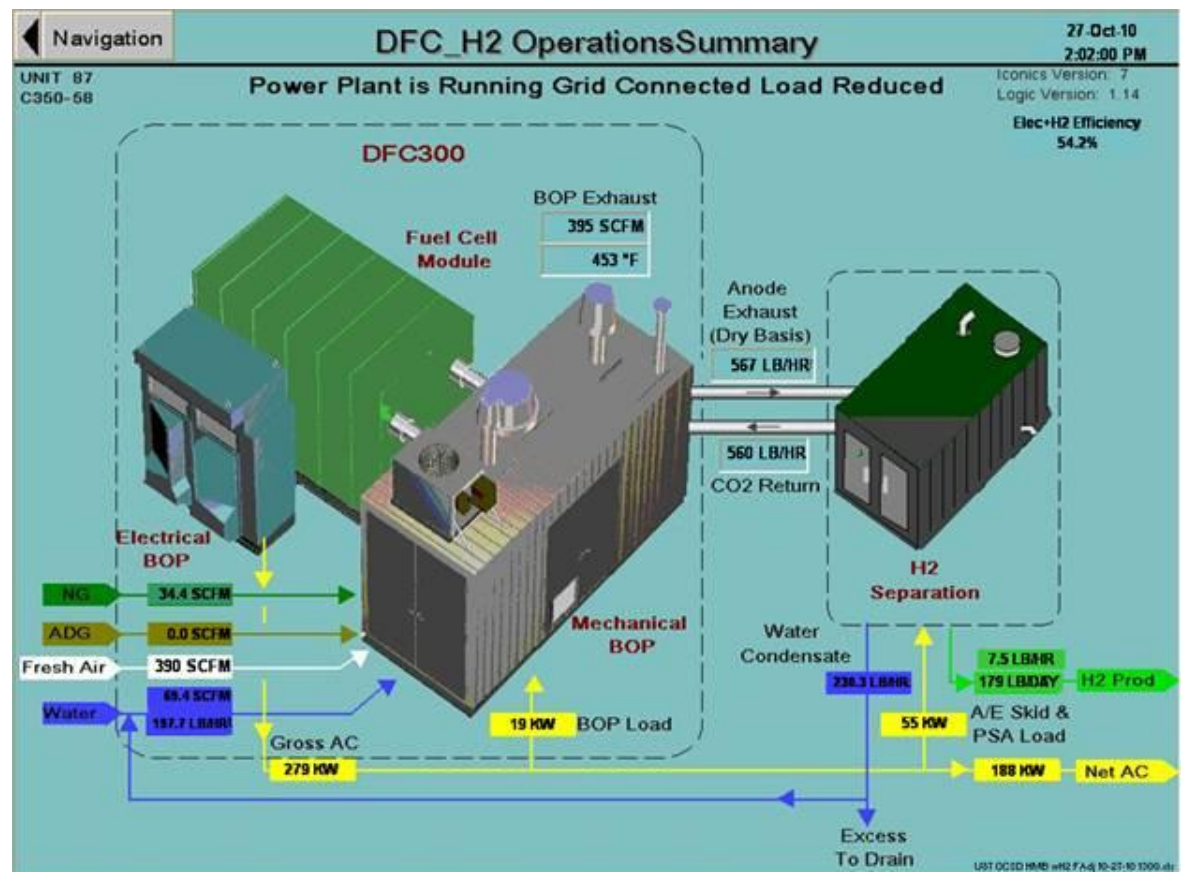

Figure 32. Snapshot of hydrogen energy station performance on 27 October 2010.

The major activities from April to June 2011 were the installation and commissioning of the ADG clean-up system (also provided under the Cooperative Agreement for the California Hydrogen Infrastructure Project). Figure 33 shows the delivery of the system to the OCSD facility. ADG was first introduced to the hydrogen energy station on 25 May 2011, and the operating parameters were tuned to allow for natural gas to be supplied automatically in case of a reduction or interruption of the ADG supply. 


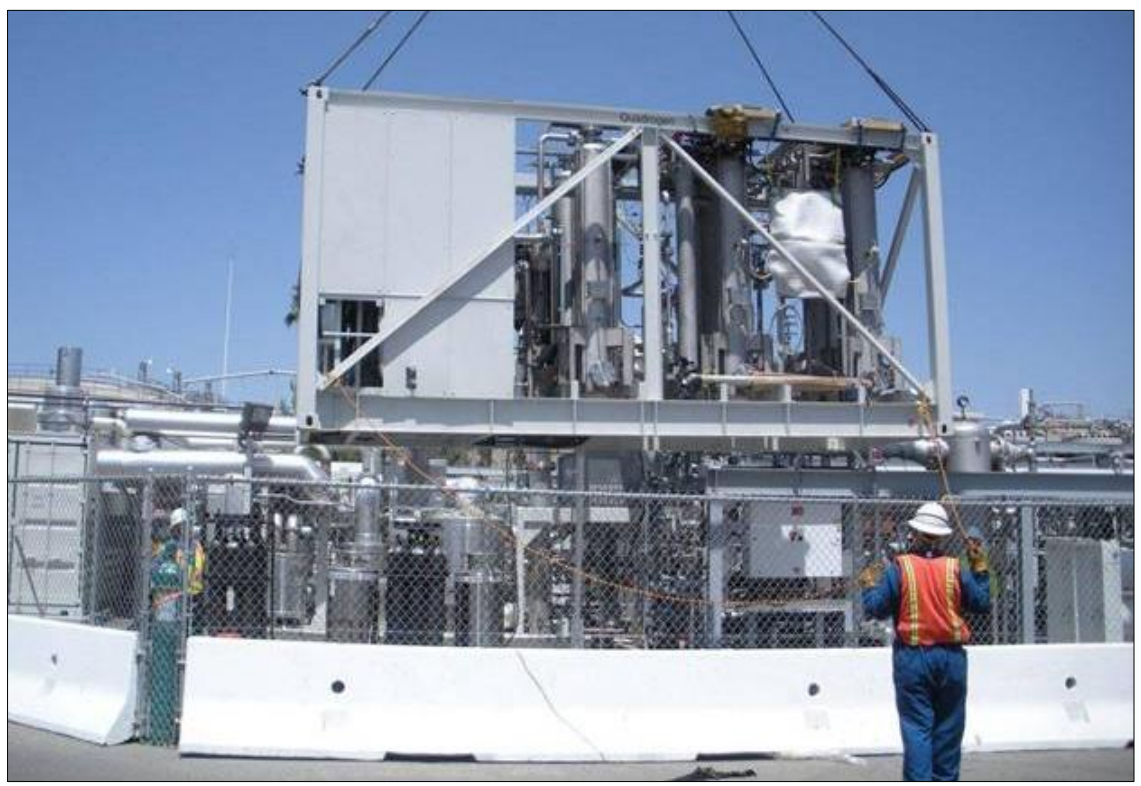

Figure 33. Installation of the ADG clean-up system at OCSD.

Figures 34 through 36 show analytical results for the inlet and outlet streams to/from the ADG clean-up system. No breakthrough of any contaminants was detected.

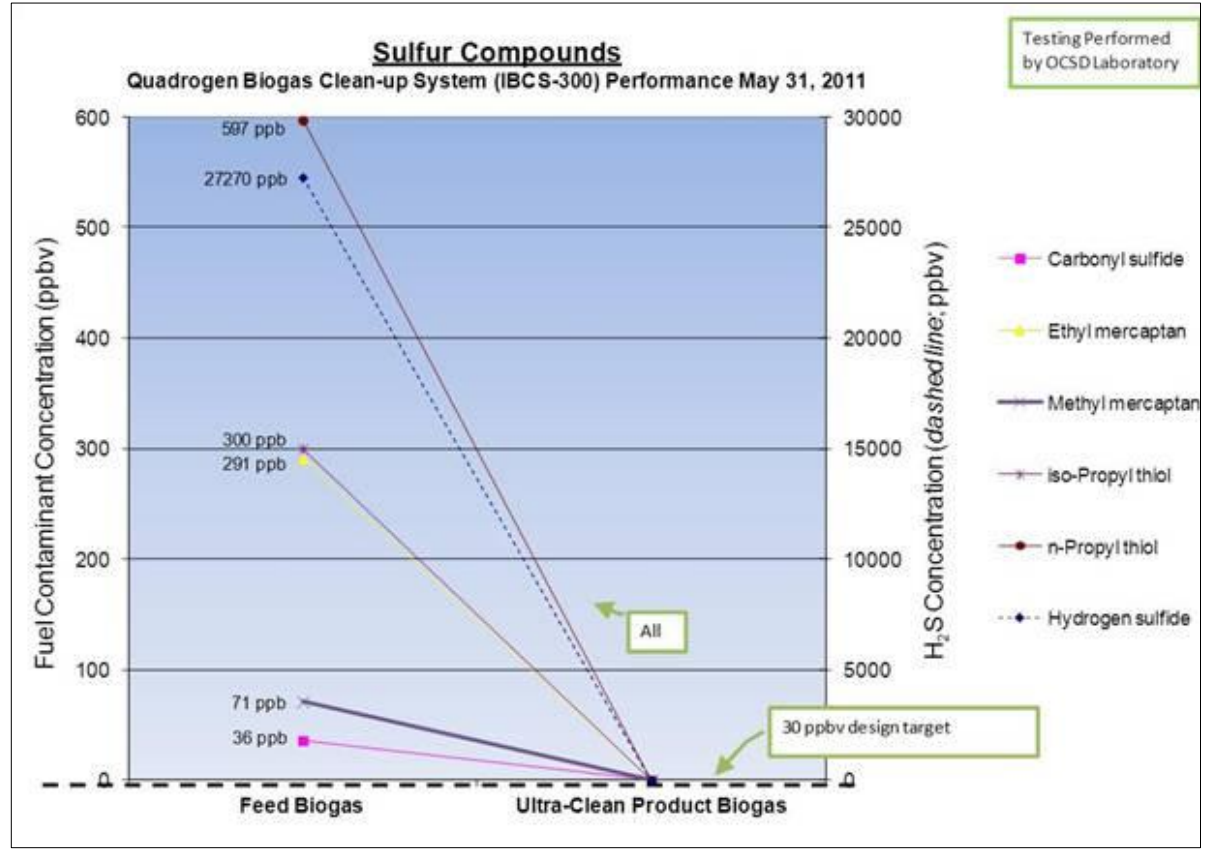

Figure 34. Performance of the ADG clean-up system on 31 May 2011. 


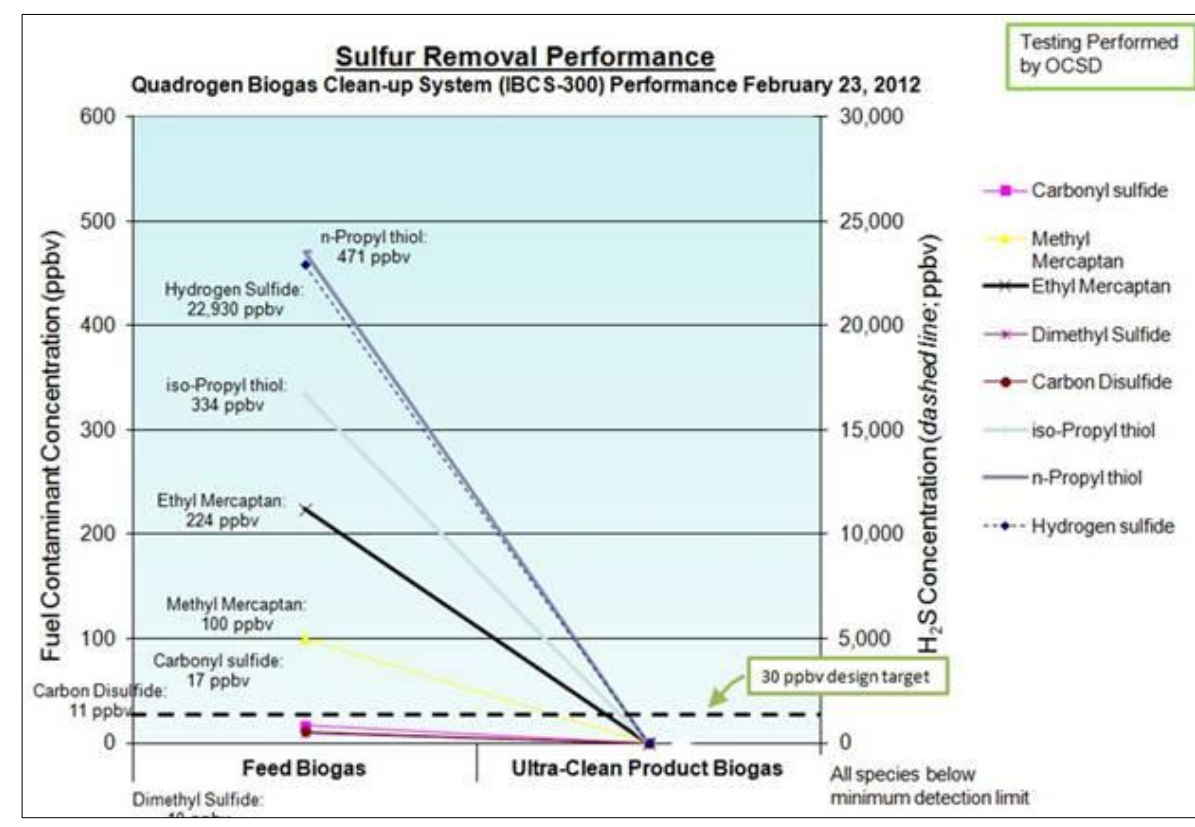

Figure 35. Performance of the ADG clean-up system on 23 February 2012.

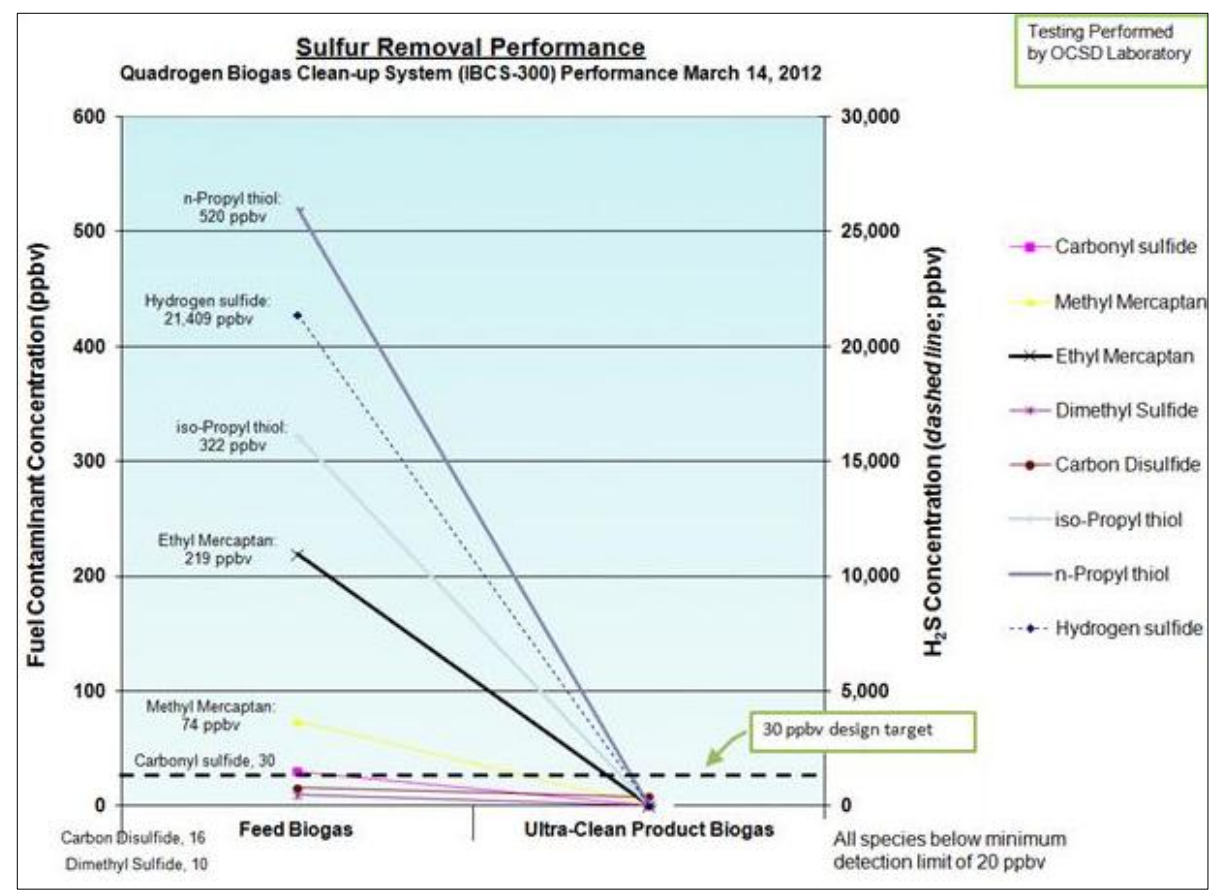

Figure 36. Performance of the ADG clean-up system on 14 March 2012.

The formal opening of the hydrogen energy station and hydrogen fueling station at OCSD was held on 16 August 2011. A total of 140 guests were in attendance. Speakers included representatives from project sponsors/participants Air Products (Tom Mutchler, Vice President, Engineering), FuelCell Energy (Tony Leo, Vice President, Applications Engineering and New Technology), the University of California, Irvine (Professor Scott Samuelsen, Ph.D. , Director, National Fuel Cell Research Center), South Coast Air Quality Management District (Miguel Pulido, AQMD Board Member, Mayor of Santa Ana, CA), California Air Resources Board 
(James Goldstene, Executive Officer), and the U.S. Department of Energy (Rick Farmer, Deputy Program Manager, Fuel Cell Technologies Program), and also included U.S. Representative Dana Rohrabacher (CA 46th District). A sample of media coverage of the event is provided below:

- NGV Global News, website that provides news for the natural gas vehicle industry: http://www.ngvglobal.com/air-products-delivers-hydrogen-fuel-from-municipal-wastewater$\underline{0816}$

- Gasworld Magazine: http://www.gasworld.com/news.php?a=5882\&dm i=3E5,IFCU,7438W,1HWAL,1

- KABC-TV, Los Angeles, CA: http://abclocal.go.com/kabc/story?section=news/local/orange county\&id=8310315

The fuel cell produced $334,933 \mathrm{kWh}$ of electricity from July to September 2011. A total of $195,018 \mathrm{kWh}$ was exported to the local grid, with the remaining power consumed by the fuel cell, digester gas clean-up, and hydrogen purification systems. The hydrogen purification system was operated as needed to generate hydrogen for storage. Independent of any fueling station usage, a portion of this hydrogen is sent from storage to the ADG clean-up system to assist in removal of sulfur species. The remaining hydrogen can then be routed back to the fuel cell instead of being vented, as was the case during initial operation in 2010.

The fuel cell continued to experience operational issues related to the power quality at the water treatment facility. A total of 115 trips (excluding trips $<15$ minutes apart) was experienced during this 3-month period. These trips limited hydrogen production, as the system was programmed to deintegrate the hydrogen purification system each time the fuel cell power production is interrupted. Changes to this logic are being considered, especially for shortduration outages through which it may be feasible to continue operating the hydrogen purifier. In September 2011, fuel cell operation was also limited due to a motor failure which took time to identify and resolve.

Operating limitations due to power quality issues continued through 31 December 2011. Figure 37 provides a summary of the total number of operating interruptions of the hydrogen energy station over the 18-month period from October 2010 to March 2012. Due to modifications within the power grid at OCSD, no trips related to power quality have occurred since 31 January 2012.

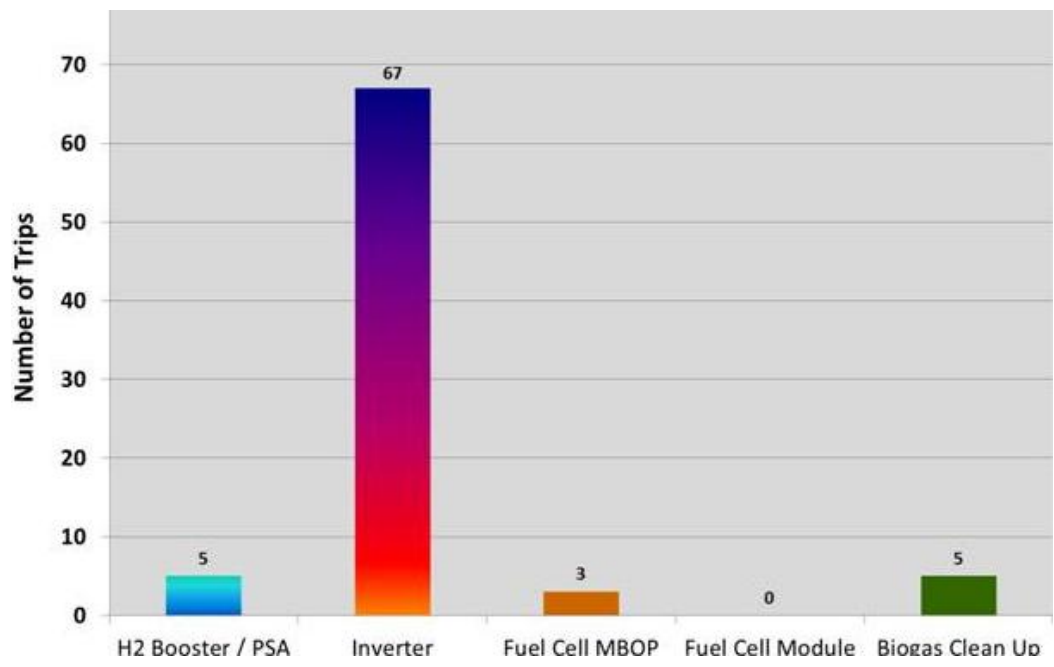

Figure 37. Causes of operating trips at OCSD, October 2010-March 2012. 
During operation on ADG, a detailed heat and material balance was performed to determine the overall efficiency of the Hydrogen energy station. As shown in Figure 38, the calculated efficiency of $53.3 \%$ exceeded the program target of $50 \%$.

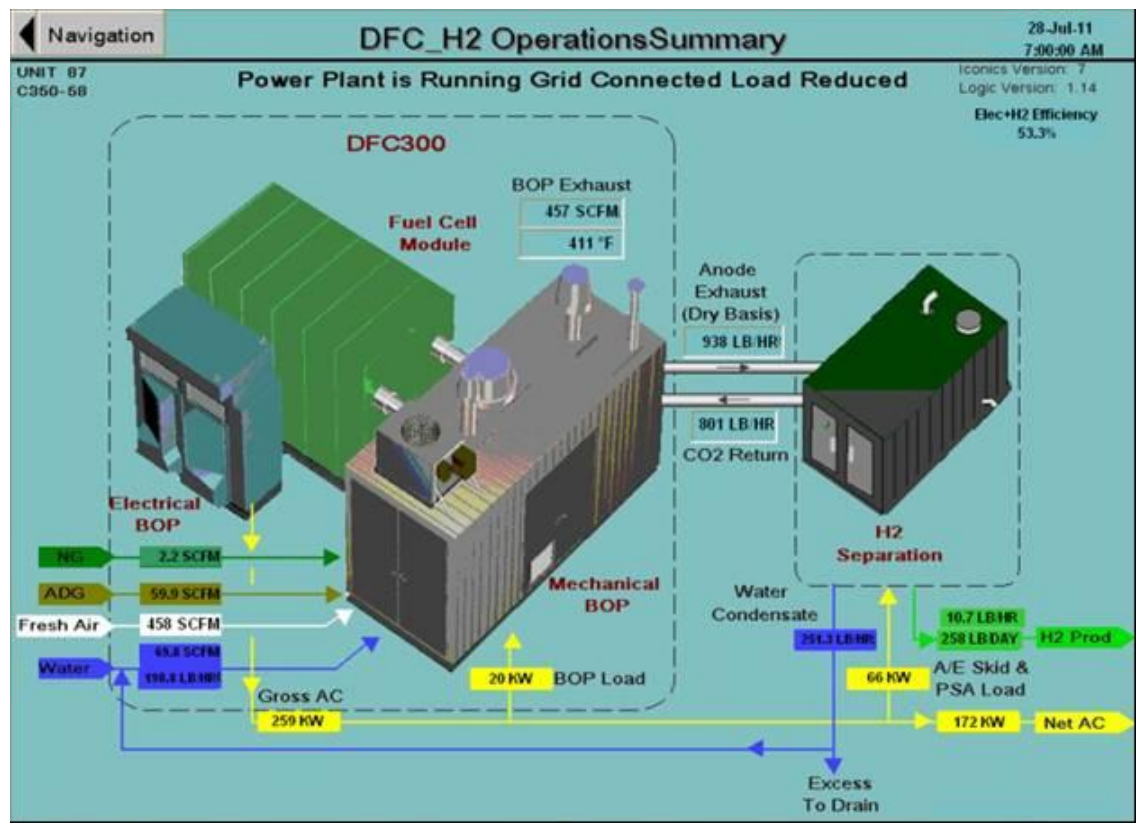

Figure 38. Snapshot of hydrogen energy station performance on 28 July 2011.

Table 5 provides a summary of three sets of efficiency calculations at OCSD, and Figure 39 tabulates the various elements of the energy balance. UC Irvine is continuing to analyze these results, with input from Air Products and FuelCell Energy, as part of their continuing research into the trigeneration process.

Table 5. Measurements of coproduction efficiency at OCSD.

\begin{tabular}{|c|c|c|}
\hline & \multicolumn{2}{|c|}{ OCSD OPERATIONS } \\
\hline & ADG 7/25/2011 & ADG 7/28/2011 \\
\hline & $\begin{array}{c}260 \mathrm{~kW} \text { Gross AC } \\
120 \mathrm{~mA} / \mathrm{cm} 2 \\
7.6 \mathrm{lb} / \mathrm{hr} \mathrm{H} 2 \\
\end{array}$ & $\begin{array}{c}260 \mathrm{~kW} \text { Gross AC } \\
120 \mathrm{~mA} / \mathrm{cm} 2 \\
10.7 \mathrm{lb} / \mathrm{hr} \mathrm{H} 2 \\
\end{array}$ \\
\hline \multicolumn{3}{|l|}{ Fuel to Fuel Cell } \\
\hline \begin{tabular}{|l|l} 
& Fuel Flow $\mathrm{R}$ \\
\end{tabular} & 58.9 & 59.9 \\
\hline Fuel Utilizat & 61.5 & 62.0 \\
\hline \begin{tabular}{l|l|} 
& Fuel Energ \\
\end{tabular} & 584 & 587 \\
\hline \multicolumn{3}{|c|}{ Electicity Export (kW) } \\
\hline \begin{tabular}{|l|l} 
& Ave Cells V \\
\end{tabular} & 0.781 & 0.777 \\
\hline Inverter Gro & 259 & 259 \\
\hline DFC BOP L & 20 & 19 \\
\hline H2 Recovel & 58 & 66 \\
\hline Electicity fo & 0 & 41 \\
\hline \begin{tabular}{l|l} 
& ADG Clean \\
\end{tabular} & 22 & 22 \\
\hline Reported Net AC & 155 & 106 \\
\hline $\begin{array}{l}\text { Reported Net A } \\
\text { Sup. Heater, Tr }\end{array}$ & 180 & 172 \\
\hline \multicolumn{3}{|c|}{ H2 Product Export } \\
\hline \begin{tabular}{|l|l|} 
& Rate $(\mathrm{lb} / \mathrm{hr})$ \\
\end{tabular} & 7.6 & 10.7 \\
\hline kW Equivalent & 114 & 162 \\
\hline Elec + H2 Efficiency & $50.4 \%$ & $53.2 \%$ \\
\hline
\end{tabular}




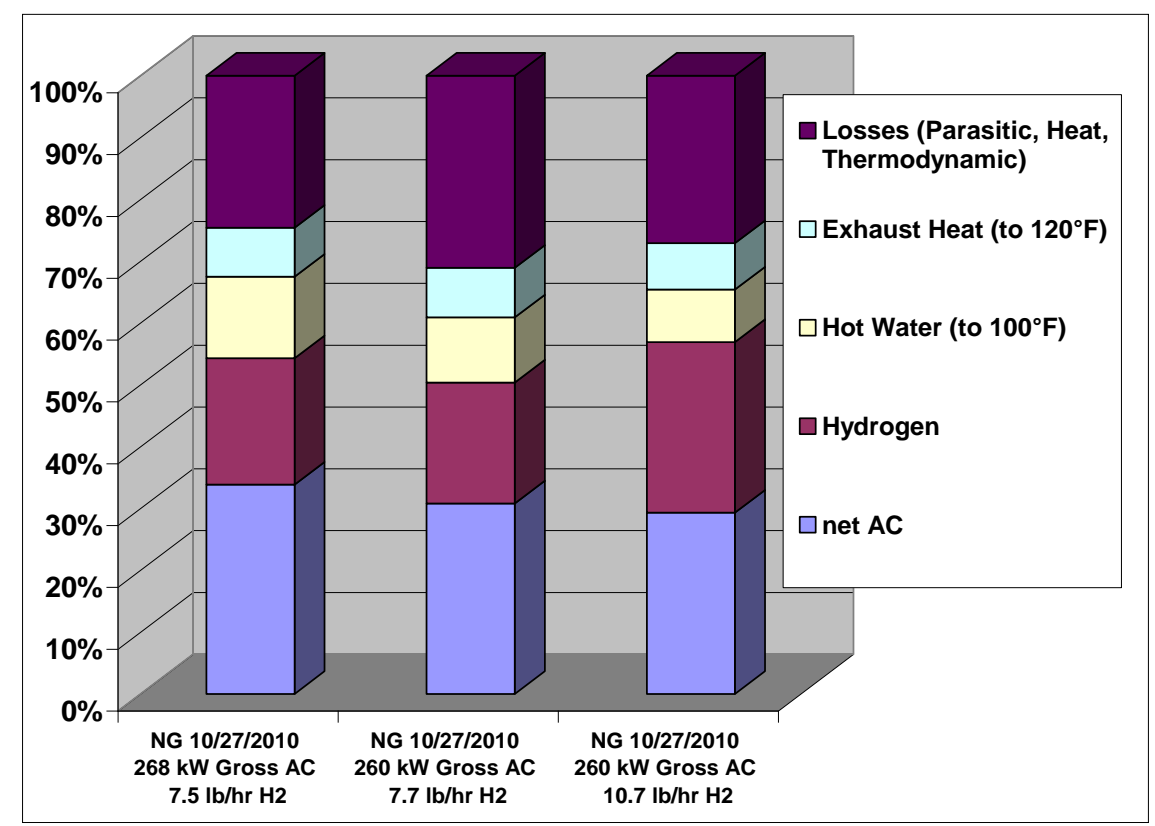

Figure 39. Measurements of coproduction efficiency at OCSD.

Figure 40 provides an overall summary of hydrogen energy station operations through April 2012. Over five million standard cubic feet of ADG was processed, and over one million $\mathrm{kWh}$ of power was exported to the power grid at OCSD.

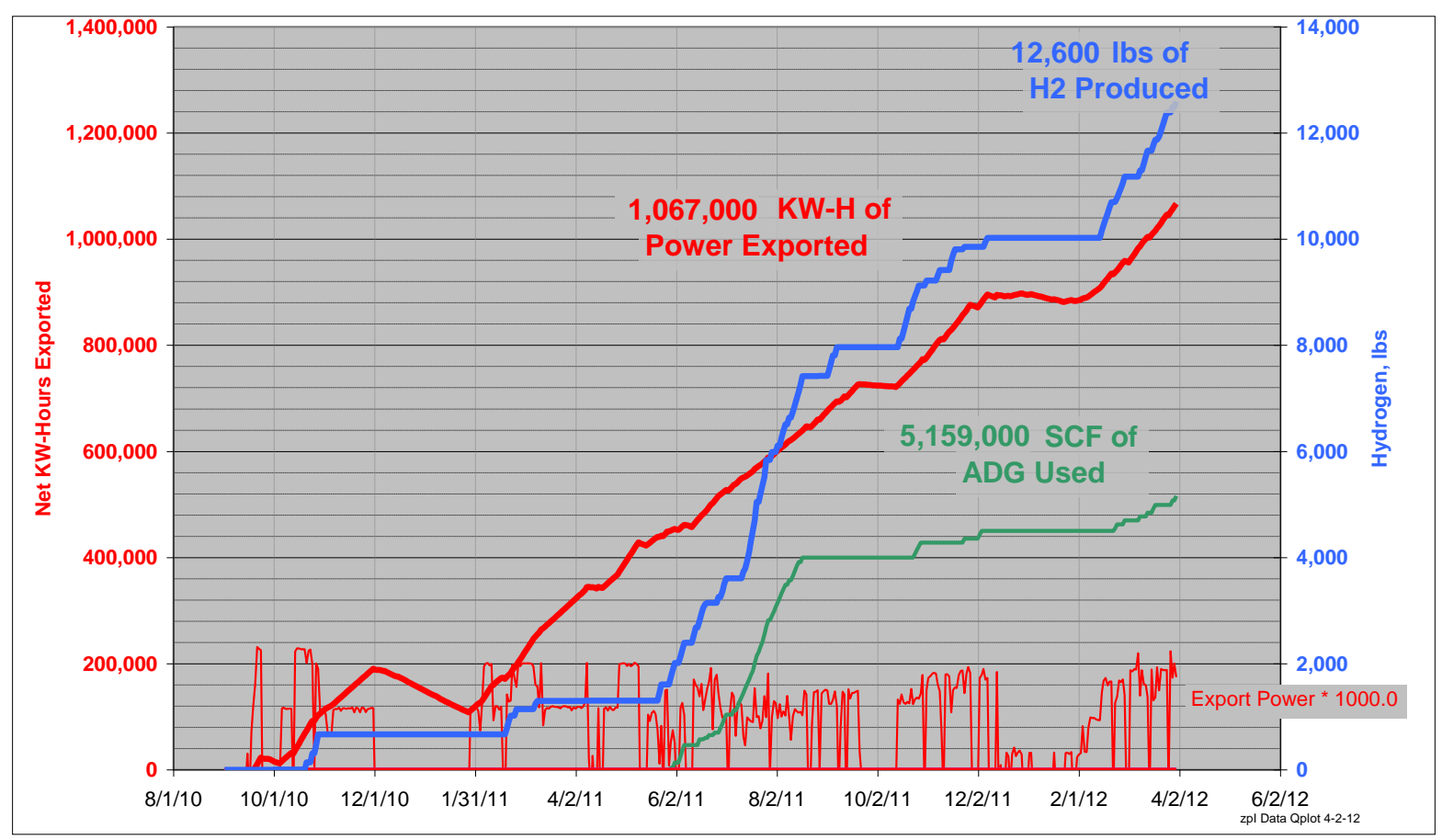

Figure 40. Operations summary at OCSD through April 2012.

Process economics for hydrogen production from a hydrogen energy station were updated based upon the results of the Phase 3 and 4 activities. Economics shown in Figure 7 were 
based upon the understanding of fuel cell and hydrogen purification costs at that stage of the project. Fuel cell costs have declined over the years, and FuelCell Energy has developed larger platforms for their molten carbonate fuel cells, including power stations as large as $10 \mathrm{MW}$. Hydrogen economics are also driven largely by the scale of production, so the updated analysis considered larger plant sizes. In addition, a different business arrangement was considered wherein the hydrogen producer purchases electricity and anode exhaust gas from the fuel cell site and returns hydrogen-depleted gas to the cathode of the fuel cell.

A financial analysis was performed using a 15-year plant life, $10 \%$ internal rate of return, overhead charge of $20 \%$ and an anode exhaust gas cost of $\$ 1$ per MMBTU. Figure 41 summarizes the results for two power prices ( $\$ 0.06$ and $\$ 0.12$ per $\mathrm{kWh}$ ) and two types of hydrogen purification technologies (near-term=pressure swing adsorption; long-term= electrochemical methods). Hydrogen pricing in the range of $\$ 5$ to $\$ 6$ per kilogram was calculated in the near term, with the potential to reduce this by $50 \%$ with improved hydrogen purification systems (e.g., electrochemical separation). These costs are competitive with renewable hydrogen produced by other means, such as electrolysis or steam-methane reforming.

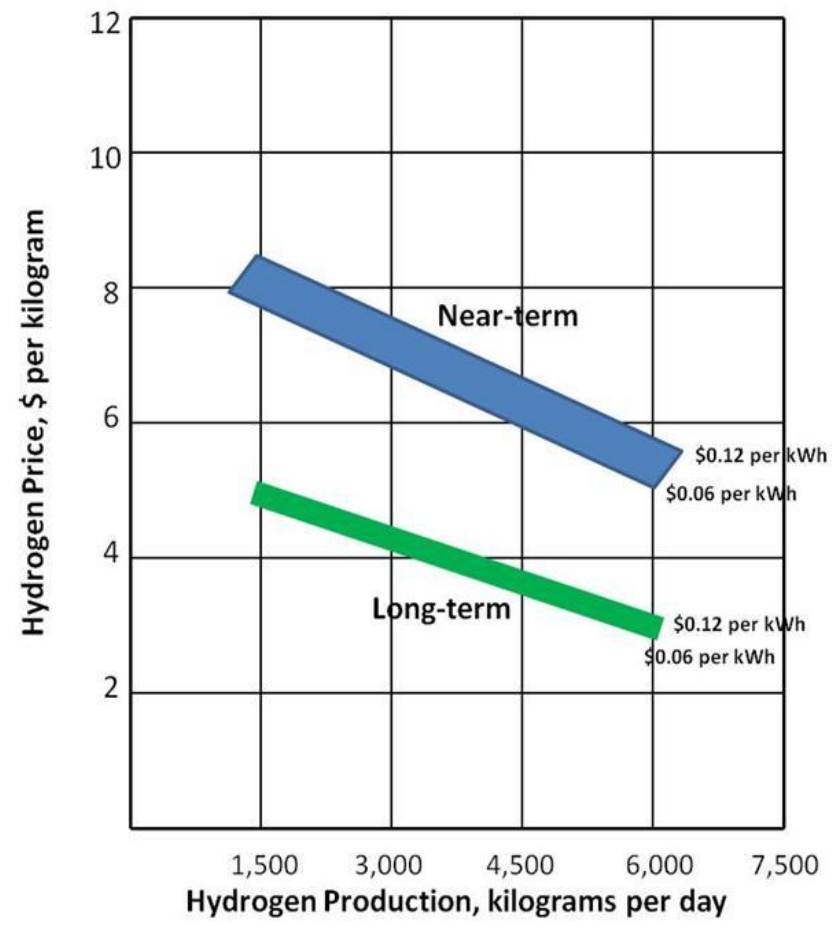

Figure 41. Hydrogen energy station economics (updated 2011). 


\section{PRESENTATIONS/PUBLICATIONS/PATENTS}

1. Poster Session at 2003 DOE Annual Program Review.

2. Keenan, G., "The Use of High Temperature Fuel Cells for Distributed Hydrogen Production," NHA Hydrogen Conference, Washington D.C., March 2005.

3. Keenan, G., "The Use of High Temperature Fuel Cells for Distributed Hydrogen Production," NHA Hydrogen Conference, March 2005, SAE Government / Industry Meeting, Washington D.C., May 2005.

4. Keenan, G., "Validation of an Integrated System for a Hydrogen-Fueled Power Park," DOE Annual Review, Washington D.C., May 2005.

5. Keenan, G. R., and Pinakin Patel, "Hydrogen Coproduction from a Molten Carbonate Fuel Cell”, 2005 Fuel Cell Seminar, November 2005, Palm Springs, CA.

6. Hydrogen Separation Technologies for Co-production of Hydrogen and Electricity; P. Patel, L. Lipp, F. Jahnke, D. Guro, D. Tyndall; Fuel Cell Seminar - 2006; Honolulu, Hawaii; November 13-17, 2006.

7. Co-production of Hydrogen and Electricity Using High Temperature Fuel Cells, P. Patel and F. Holcomb, FuelCell 2007, $5^{\text {th }}$ International ASME Conference, New York, NY, June 2007.

8. Transition to a Hydrogen Economy, E. F. Kiczek, Great Plains Energy Expo, 29 October 2007.

9. Flexible Co-Production of Renewable Hydrogen and Electricity, P. Patel, L. Lipp, F. Jahnke, D. Tyndall and F. Holcomb, Fuel Cell Seminar, San Antonio, TX, October 2007.

10. Renewable H2 from DFC@ Fuel Cell, Renewable Hydrogen Co-Production from a High Temperature Fuel Cell, F. Jahnke, P. Patel, D. Tyndall, and F. Holcomb, 2008 NHA Conference, Sacramento, CA, March 30, 2008.

11. Renewable Hydrogen energy station - A Sustainable Path Forward, D. Tyndall and P. Patel, 2008 CGA Hydrogen Seminar, Sacramento, CA - April 3, 2008.

12. A presentation regarding the overall project status was given at the DOE Annual Merit Review Meeting (June 2008).

13. Presentation at the "Future is Green" Conference sponsored by the California Air Pollution Control Officers Association, Long Beach, CA, September 2008.

14. Presentation at National Hydrogen Association Fall Forum on Renewable Hydrogen, Golden, CO, September 2008.

15. Presentation at Fuel Cell Seminar 2008, Phoenix, AZ, October 2008.

16. Panel presentation at DOE-EERE Workshop on Integration of Stationary Fuel Cells in Transportation Fuel Cell Applications, Phoenix, AZ, October 2008.

17. Presentation at National Hydrogen Association 2009 Conference, Columbia, SC, April 2009.

18. Presentation at the DOE Annual Merit Review Meeting, Arlington, VA, May 2009.

19. Presentation at Canadian Hydrogen Fuel Cell Conference 2009, Vancouver, CN, June 2009.

20. Presentation at DOE Trigeneration Workshop at UC Irvine and ASME International Conference, Newport Beach, CA, June 2009.

21. Presentation at 2009 FuelCell Seminar, Palm Springs, CA, November 2009.

22. Presentation at DOE-NREL Renewables-to-Hydrogen Workshop, Palm Springs, CA, November 2009.

23. Presentation at IPHE Meeting, Washington, DC, December 2009.

24. Paper and Oral Presentation at ICEPAG 2010, Costa Mesa, CA, February 2010.

25. Presentation at the DOE Annual Merit Review Meeting, Washington, DC, June 2010.

26. Presentation at the DOE Annual Merit Review Meeting, Washington, DC, May 2011.

27. Presentation at the DOE Annual Merit Review Meeting, Washington, DC, May 2012.

A US Patent (US 7,695,545) "Adsorption process to recover hydrogen from feed gas mixtures having low hydrogen concentration" was assigned to Air Products and Chemicals, Inc. on 13 April 2010. 